OPEN ACCESS

Edited by:

Heqing Jiang,

Qingdao Institute of Bioenergy and Bioprocess Technology (CAS), China

Reviewed by:

Yan Zhang,

Qingdao Institute of Bioenergy and Bioprocess Technology (CAS), China

Mingxing $W u$,

Hebei Normai University, China

*Correspondence:

Dmitriy I. Potemkin

potema@catalysis.ru

Alexei A. Lapkin

aal35@cam.ac.uk

Specialty section

This article was submitted to

Chemical Engineering,

a section of the journal

Frontiers in Chemistry

Received: 30 January 2018 Accepted: 12 March 2018

Published: 27 March 2018

Citation:

Potemkin DI, Maslov DK, Loponov K, Snytnikov PV, Shubin W, Plyusnin PE,

Svintsitskiy DA, Sobyanin VA and

Lapkin AA (2018) Porous

Nanocrystalline Silicon Supported

Bimetallic Pd-Au Catalysts:

Preparation, Characterization, and Direct Hydrogen Peroxide Synthesis.

Front. Chem. 6:85

doi: 10.3389/fchem.2018.00085

\section{Porous Nanocrystalline Silicon Supported Bimetallic Pd-Au Catalysts: Preparation, Characterization, and Direct Hydrogen Peroxide Synthesis}

\author{
Dmitriy I. Potemkin ${ }^{1,2 *}$, Dmitry K. Maslov' ${ }^{2}$ Konstantin Loponov ${ }^{3}$, Pavel V. Snytnikov ${ }^{1,2}$, \\ Yuri V. Shubin ${ }^{1,4}$, Pavel E. Plyusnin ${ }^{1,4}$, Dmitry A. Svintsitskiy ${ }^{1,2}$, Vladimir A. Sobyanin ${ }^{2}$ and \\ Alexei A. Lapkin ${ }^{3,5 *}$

\begin{abstract}
'Laboratory of the Energy-Efficient Catalytic Processes, Novosibirsk State University, Novosibirsk, Russia, ${ }^{2}$ Department of Heterogeneous Catalysis, Boreskov Institute of Catalysis, Novosibirsk, Russia, ${ }^{3}$ Department of Chemical Engineering and Biotechnology, University of Cambridge, Cambridge, United Kingdom, ${ }^{4}$ Laboratory of the Rare Platinum Metals Chemistry, Nikolaev Institute of Inorganic Chemistry, Novosibirsk, Russia, ${ }^{5}$ Cambridge Centre for Advanced Research and Education in Singapore Ltd., Singapore, Singapore
\end{abstract}

Bimetallic Pd-Au catalysts were prepared on the porous nanocrystalline silicon (PSi) for the first time. The catalysts were tested in the reaction of direct hydrogen peroxide synthesis and characterized by standard structural and chemical techniques. It was shown that the $\mathrm{Pd}-\mathrm{Au} / \mathrm{PSi}$ catalyst prepared from conventional $\mathrm{H}_{2}\left[\mathrm{PdCl}_{4}\right]$ and $\mathrm{H}\left[\mathrm{AuCl}_{4}\right]$ precursors contains monometallic $\mathrm{Pd}$ and a range of different $\mathrm{Pd}$-Au alloy nanoparticles over the oxidized PSi surface. The $\mathrm{PdAu}_{2} / \mathrm{PSi}$ catalyst prepared from the $\left[\mathrm{Pd}\left(\mathrm{NH}_{3}\right)_{4}\right]\left[\mathrm{AuCl}_{4}\right]_{2}$ double complex salt (DCS) single-source precursor predominantly contains bimetallic Pd-Au alloy nanoparticles. For both catalysts the surface of bimetallic nanoparticles is $\mathrm{Pd}$-enriched and contains palladium in $\mathrm{Pd}^{0}$ and $\mathrm{Pd}^{2+}$ states. Among the catalysts studied, the $\mathrm{PdAu}_{2} / \mathrm{PSi}$ catalyst was the most active and selective in the direct $\mathrm{H}_{2} \mathrm{O}_{2}$ synthesis with $\mathrm{H}_{2} \mathrm{O}_{2}$ productivity of $0.5 \mathrm{~mol} \mathrm{~g}_{\mathrm{Pd}}^{-1} \mathrm{~h}^{-1}$ at selectivity of $50 \%$ and $\mathrm{H}_{2} \mathrm{O}_{2}$ concentration of $0.023 \mathrm{M}$ in $0.03 \mathrm{M} \mathrm{H}_{2} \mathrm{SO}_{4}$-methanol solution after $5 \mathrm{~h}$ on stream at $-10^{\circ} \mathrm{C}$ and atmospheric pressure. This performance is due to high activity in the $\mathrm{H}_{2} \mathrm{O}_{2}$ synthesis reaction and low activities in the undesirable $\mathrm{H}_{2} \mathrm{O}_{2}$ decomposition and hydrogenation reactions. Good performance of the $\mathrm{PdAu}_{2} / \mathrm{PSi}$ catalyst was associated with the major part of $\mathrm{Pd}$ in the catalyst being in the form of the bimetallic $\mathrm{Pd}-\mathrm{Au}$ nanoparticles. Porous silicon was concluded to be a promising catalytic support for direct hydrogen peroxide synthesis due to its inertness with respect to undesirable side reactions, high thermal stability, and conductivity, possibility of safe operation at high temperatures and pressures and a well-established manufacturing process.

Keywords: direct $\mathrm{H}_{2} \mathrm{O}_{2}$ synthesis, direct hydrogen peroxide synthesis, porous silicon, bimetallic nanoparticles, alloy nanoparticles, Pd-Au catalysts, gold-palladium catalysts, double complex salts 


\section{INTRODUCTION}

In the general field of industrial chemistry the role of heterogeneous catalysis is difficult to overestimate: the advances in large-scale catalytic processes, such as ammonia synthesis, sulphuric acid and nitric acid processes, ethylene and propylene production, acetic acid, and methanol syntheses and several others were responsible for the rapid development of human civilization in the twentieth-century. In the twenty-first century the challenges for catalysis are different but, arguably, even harder than those that were solved till now: selective activation of $\mathrm{C}-\mathrm{H}$ bonds in saturated alkanes, efficient and selective activation of $\mathrm{CO}_{2}$, efficient splitting of water, highly selective functionalization of complex molecules for pharmaceutical and speciality chemicals, etc. These challenges have one common aspect-the requirement for much better control of reaction selectivity in the traditionally "difficult" reactions, such as sp3 C-H activation, as an example. The requirement for better selectivity control marks the need for a very different approach to catalysts design to that traditionally practiced in the twentieth-century for bulk processes: highly dispersed and uniform active sites are preferred (Flytzani-Stephanopoulos and Gates, 2012) and often polyfunctionality is required (Climent et al., 2014). Many conventional heterogeneous catalysts are highly heterogeneous in the nature of their active sites. For this reason, a significant effort in current research in the field of heterogeneous catalysis is on developing new methods of synthesis of heterogeneous catalysts, that result in much tighter control of the structure and composition of the active sites. Advanced synthesis techniques are under development: from modified impregnation and adsorption (Munnik et al., 2015) to a novel approach of nanoparticles biosynthesis which presents an alternative eco-friendly and potentially precise way for synthesis of heterogeneous catalysts (Hulkoti and Taranath, 2014).

Novel support materials do not frequently appear in catalytic literature and most conventionally-used supports, such as mixed oxides or carbon, are not well-suited to the challenge of precise control of selectivity due to their inherent heterogeneity. For this reason, significant attention is currently paid to "structured" supports, such as MOFs (Dhakshinamoorthy et al., 2013; Zhao et al., 2016), 2D materials such as graphene (Fan et al., 2015; Julkapli and Bagheri, 2015), 1D materials such as carbon nanotubes (Serp and Castillejos, 2010; Yan et al., 2015) or titanate nanotubes (Bavykin et al., 2005), and so on. Among the many support materials usually investigated in catalysis silicon is one of less known and little studied to date.

Its application as a catalyst support was first discussed in Polisski et al. (2010). PSi is a high surface area semiconducting material with high heat conductivity and pore structure very interesting for catalysis - a network of open pores with pore sizes in the mesopore range of 2-6 $\mathrm{nm}$ (Künzner et al., 2003); the electrochemical pore formation in silicon having been studied in detailed earlier (Lehmann et al., 2000). The high surface area of porous silicon (PSi) is hydrogen-terminated. This hydrogen can facilitate reduction of dissolved metal salts directly at the surface, without the use of additional reducing agents (Polisski et al., 2008). This can be exploited to produce small dispersed metal nanoparticles inside PSi pores from alcoholic metal salt solutions. This synthesis method resulted in metal nanoparticles in the range of $5-10 \mathrm{~nm}$, located largely within the pores of the support. This is distinct from the earlier reports of metal/PSi composites obtained from aqueous metal salt solutions using metal hydrides or hydrogen as reducing agents, which result in the formation of much larger metal particles (Coulthard et al., 1993, 2000; Coulthard and Sham, 1998). Similarly, the surfactant mediated method using sodium borohydride as reducing agent in aqueous-ethanol solution results in the formation of large metal nanoparticles in the range of 10-50 $\mathrm{nm}$ (Yashtulov et al., 2011, 2016).

In recent years there is a significant increase in the number of publications devoted to different synthesis methods and application fields of metal-PSi materials. To cite only few studies, porous silicon was used to synthesize nano-composite materials for lithium-ion batteries (Zhai et al., 2017), as a stoichiometric reducing agent for direct conversion of $\mathrm{CO}_{2}$ to methanol (Dasog et al., 2017), as a support for Pd nanoparticles in catalytic oxidation of formic acid (Yashtulov and Flid, 2013), in a detailed experimental and theoretical investigation of the electronic structure and gas adsorption on $\mathrm{Pd}, \mathrm{Cu}, \mathrm{Pd}-\mathrm{Cu}$, and $\mathrm{WO}_{3}-\mathrm{Pd}$ nanoparticles supported on porous silicon for gas sensing applications (Litovchenko et al., 2017), for developing Pt$\mathrm{Pd} / \mathrm{PSi}$ electrocatalysts for direct methanol fuel cell (Ensafi et al., 2015). There are no new works on developing heterogeneous catalysts for chemical processes. Thus, in order to expand current knowledge on catalysis by porous silicon-supported catalysts we chose a difficult and very important industrial chemistry reaction of direct synthesis of hydrogen peroxide.

Hydrogen peroxide is an excellent oxidizing reagent for the production of both fine and bulk chemicals that finds applications also in the area of wastewater treatment, paper and pulp bleaching, and widely used in healthcare. Most of the world's hydrogen peroxide is currently produced by the sequential hydrogenation and oxidation of an alkyl anthraquinone (Bernardotto et al., 2009). This process suffers from several limitations, such as significant amount of organic waste, need of several energy consuming separation and concentration steps and economic feasibility only in large-scale (Menegazzo et al., 2015).

The direct synthesis of $\mathrm{H}_{2} \mathrm{O}_{2}$ from hydrogen and oxygen in methanol or water reaction media provides a more atom efficient route to the current commercial production process. The direct route would enable $\mathrm{H}_{2} \mathrm{O}_{2}$ production to take place at its point of use, reducing the transportation costs, and for this reason there is a significant interest in developing such a catalytic process. The minimal required $\mathrm{H}_{2} \mathrm{O}_{2}$ concentration produced by the direct synthesis for practical use is estimated to be $1 \mathrm{wt} . \%$ or $0.23 \mathrm{M}$ in methanol solution (Garcia-Serna et al., 2014). Figure 1 represents reactions involved in the direct $\mathrm{H}_{2} \mathrm{O}_{2}$ production process (Bernardotto et al., 2009). Besides the target $\mathrm{H}_{2} \mathrm{O}_{2}$ synthesis reaction, undesirable total $\mathrm{H}_{2}$ oxidation together with $\mathrm{H}_{2} \mathrm{O}_{2}$ hydrogenation and decomposition reactions could occur. Thus, catalyst's ability to synthesize $\mathrm{H}_{2} \mathrm{O}_{2}$ selectively and avoid its hydrogenation and decomposition becomes the key 


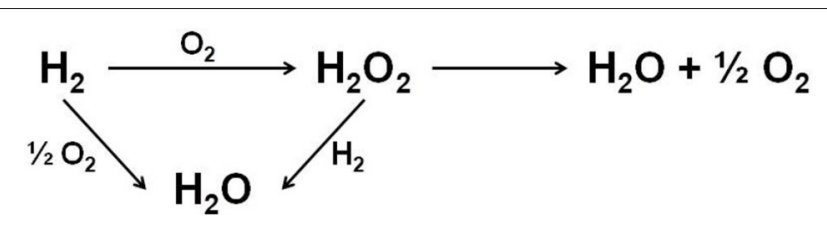

FIGURE 1 | A general scheme of reactions involved in the direct $\mathrm{H}_{2} \mathrm{O}_{2}$ synthesis process.

factor to reach high $\mathrm{H}_{2} \mathrm{O}_{2}$ concentrations with acceptable atomic and economic efficiencies.

Several reviews (Samanta, 2008; Dittmeyer et al., 2015; Edwards et al., 2015; Yi et al., 2016; Seo et al., 2017) consider catalytic systems, reaction conditions, and engineering concepts for direct $\mathrm{H}_{2} \mathrm{O}_{2}$ synthesis. Several bimetallic Pd-based systems show promising levels of performance in the direct $\mathrm{H}_{2} \mathrm{O}_{2}$ synthesis: Pd-Au (Edwards et al., 2005, 2009), Pd-Pt (Bernardotto et al., 2009), Pd-Ni (Maity and Eswaramoorthy, 2016), novel Pd-Te (Tian et al., 2017), and Pd-Ag (Gu et al., 2016) and the recently published Pd-Sn (Freakley et al., 2016), exhibiting a very high level of performance. Among other systems the Pd-Au one exhibiting selectivities up to 95\% (Edwards et al., 2009) is the most extensively studied. Earlier studies have shown that bimetallic alloy $\mathrm{Pd}-\mathrm{Au}$ nanoparticles, probably with $\mathrm{Pd}$ enriched shell (Edwards et al., 2005), are responsible for high activity and selectivity in $\mathrm{H}_{2} \mathrm{O}_{2}$ synthesis. The surface ratio of $\mathrm{Pd}^{0} / \mathrm{Pd}^{2+}$ in the AuPd alloy was found to be an important factor controlling the overall catalyst performance. A stable nonleaching form of $\mathrm{Pd}^{2+}$ was identified as a key feature in highly selective PdAu catalysts (Edwards et al., 2012). Catalyst surface and/or reaction media acidity play important role in the reaction. Highly acidic cesium salts of Keggin-type tungstophosphoric acid $\left(\mathrm{Cs}_{\mathrm{x}} \mathrm{H}_{3-\mathrm{x}} \mathrm{PW}_{12} \mathrm{O}_{40}\right)$ were proposed as the best support materials, providing better performance than carbon and metal oxides supports (Ntainjua et al., 2012). A reversible high-pressure $\mathrm{CO}_{2}$-derived acidification of combined water-methanol reaction media (Freakley et al., 2013) was successfully applied for high pressure operations. It should also be noted that in spite of huge efforts to determine the surface structure of bimetallic Pd$\mathrm{Au}$ catalysts active for the $\mathrm{H}_{2} \mathrm{O}_{2}$ direct synthesis, the detailed understanding of the active sites of the metal nanoparticles remains elusive.

The selective formation of bimetallic $\mathrm{Pd}-\mathrm{Au}$ nanoparticles in supported catalysts is desirable to obtain highly selective direct $\mathrm{H}_{2} \mathrm{O}_{2}$ synthesis catalyst, due to ability of monometallic $\mathrm{Pd}$ particles to catalyze hydrogenation of $\mathrm{H}_{2} \mathrm{O}_{2}$ (Edwards et al., 2015), thereby limiting the achievable $\mathrm{H}_{2} \mathrm{O}_{2}$ maximum concentration and decreasing process selectivity. Within this context we applied the approach based on decomposition of double complex salts (DCS) inside the pores of a support material for the synthesis of the bimetallic $\mathrm{Pd}-\mathrm{Au}$ direct $\mathrm{H}_{2} \mathrm{O}_{2}$ synthesis catalyst. DCSs of transition metals, coordination compounds with the common formula $\left[M^{\prime} L_{n}^{\prime}\right]_{x}\left[M^{\prime \prime} L^{\prime \prime}\right]_{y}$, where $M^{\prime}$ and $M^{\prime \prime}$ are metals, $\mathrm{L}^{\prime}$ and $\mathrm{L}^{\prime \prime}$ are different ligands, have a number of advantages as single-source precursors of bimetallic catalysts:
- Complexing metals in a DCS are "mixed" on a molecular level that allows formation of alloys upon salt decomposition;

- Stoichiometry of a precursor complex determines composition of the alloys;

- Ability to preset exact phase composition and morphology of the alloy nanoparticles, varying the DCS deposition process, and decomposition conditions.

The successful application of DCS for catalyst preparation was demonstrated in a number of works (Potemkin et al., 2012, 2014, 2017; Shubin et al., 2012; Simonov et al., 2012; Bulushev et al., 2013; Vedyagin et al., 2013, 2014). To provide $\mathrm{Pd}-\mathrm{Au}$ interaction and to promote alloy formation we have chosen $\left[\mathrm{Pd}\left(\mathrm{NH}_{3}\right)_{4}\right]\left[\mathrm{AuCl}_{4}\right]_{2}$ DCS as a single-source precursor. Its properties and application as a precursor for bimetallic $\mathrm{Pd}-\mathrm{Au}$ nanoparticles were discussed in Shubin et al. (2012), Bulushev et al. (2013), Simonov et al. (2012), and Plyusnin et al. (2007). Due to the fact, that $\mathrm{Pd}$ and $\mathrm{Au}$ atoms are premixed in the precursor, $\left[\mathrm{Pd}\left(\mathrm{NH}_{3}\right)_{4}\right]\left[\mathrm{AuCl}_{4}\right]_{2}$ reduction inside the pore space at mild conditions leads to the selective formation of supported $\mathrm{Pd}-\mathrm{Au}$ alloy nanoparticles without intermediate formation of $\mathrm{Pd}$ and Au phases and its alloying.

Besides the composition and structure of metallic component the choice of support plays an important role in designing direct $\mathrm{H}_{2} \mathrm{O}_{2}$ synthesis catalysts. Support's properties, such as red-ox interaction with $\mathrm{Pd}$, wettability by reaction media, inertness with regard to $\mathrm{H}_{2} \mathrm{O}_{2}$ decomposition and hydrogenation, surface acidity are of special attention. Carbon supports (Edwards et al., 2009), titania (Edwards et al., 2005), Keggin-type heteropolyacids (Ntainjua et al., 2012), sulfated ceria and zirconia (Menegazzo et al., 2015) are considered as conventional choice for direct $\mathrm{H}_{2} \mathrm{O}_{2}$ synthesis catalysts. However, the search for alternative supports is still actual, especially in the scope of further reaction translation from lab-scale batch reactors to more practical and scalable continuous flow multiphase reactors, in which the application of conventional catalysts powders is limited by the need of its fixing and mass-/heat-transfer problem.

In this regard we investigated the properties of porous nanocrystalline silicon powder (PSi) as a support for $\mathrm{Pd}-\mathrm{Au}$ direct $\mathrm{H}_{2} \mathrm{O}_{2}$ synthesis catalysts. We report results on preparation, characterization and catalytic tests of bimetallic PSi supported $\mathrm{Pd}-\mathrm{Au}$ catalysts prepared by $\left[\mathrm{Pd}\left(\mathrm{NH}_{3}\right)_{4}\right]\left[\mathrm{AuCl}_{4}\right]_{2}$ single-source precursor decomposition. To our knowledge it is the first report of such catalytic system and extends the knowledge of porous silicon as a promising catalyst support. The comparison with monometallic PSi supported Pd and Au catalysts, and bimetallic $\mathrm{Pd}-\mathrm{Au}$ catalyst, prepared utilizing conventional $\mathrm{H}_{2}\left[\mathrm{PdCl}_{4}\right]$ and $\mathrm{H}\left[\mathrm{AuCl}_{4}\right]$ precursors, were done as well.

\section{EXPERIMENTAL}

\section{Materials}

Porous nanocrystalline silicon with average grain size of $4 \mu \mathrm{m}$ was supplied by Vesta Ceramics. All other chemicals were commercially purchased and used without additional purification. 


\section{Catalyst Preparation}

All catalysts were prepared by the metals reduction from its salts solutions by PSi's surface $\mathrm{H}$-terminal atoms by the protocol adapted from Polisski et al. (2010).

The Pd loading in all catalysts was set to $2 \mathrm{wt}$.\% which is close to optimal value according to literature (Edwards et al., 2005).

The synthesized $\left[\mathrm{Pd}\left(\mathrm{NH}_{3}\right)_{4}\right]\left[\mathrm{AuCl}_{4}\right]_{2}$ DCS was used as a single-source precursor for the $\mathrm{PdAu}_{2} / \mathrm{PSi}$ catalyst. The $\mathrm{Pd}$ and $\mathrm{Au}$ loadings were set to 2 and $7.4 \mathrm{wt} \%$ according to $\left[\mathrm{Pd}\left(\mathrm{NH}_{3}\right)_{4}\right]\left[\mathrm{AuCl}_{4}\right]_{2}$ stoichiometry. A portion of $2 \mathrm{~g}$ of PSi powder was added to $50 \mathrm{~mL}$ of the DCS acetone solution of the required concentration at $-15^{\circ} \mathrm{C}$ under vigorous stirring. Acetone solvent was used to attain wetting of the hydrophobic $\mathrm{H}$ terminated surface of PSi and due to high $\left[\mathrm{Pd}\left(\mathrm{NH}_{3}\right)_{4}\right]\left[\mathrm{AuCl}_{4}\right]_{2}$ solubility in acetone. The suspension was kept at $-15^{\circ} \mathrm{C}$ for $1 \mathrm{~h}$ under vigorous stirring, and then temperature was slowly increased to ambient. The obtained catalyst was filtered, washed several times with acetone and warm water to dissolve possible residual salts in pores, and dried at room temperature on air.

Bimetallic Pd-Au/PSi catalyst was prepared according to the procedure described above using the conventional $\mathrm{H}_{2}\left[\mathrm{PdCl}_{4}\right]$ and $\mathrm{H}\left[\mathrm{AuCl}_{4}\right]$ joint water-ethanol solution as a metal source. The $\mathrm{Pd}$ and Au loadings for Pd-Au/PSi catalyst were set to 2 wt.\%, which are close to the optimal values according to the literature data (Edwards et al., 2009).

Monometallic $\mathrm{Pd} / \mathrm{PSi}$ and $\mathrm{Au} / \mathrm{PSi}$ catalysts were prepared using the same protocol with water-acetone solutions of $\left[\mathrm{Pd}\left(\mathrm{NH}_{3}\right)_{4}\right]\left(\mathrm{NO}_{3}\right)_{2}$ and $\mathrm{H}\left[\mathrm{AuCl}_{4}\right]$ as precursors.

\section{Catalytic Activity Study}

Catalytic tests were carried out at atmospheric pressure at $-10^{\circ} \mathrm{C}$ in a thermostated glass reactor. Mixing was carried out with an inert rotor operating at $400 \mathrm{rpm}$. Oxygen and hydrogen were bubbled by a gas diffuser directly into the liquid phase with a total flow of $50 \mathrm{ml}$ (STP) $\mathrm{min}^{-1}$. A non-explosive gas mixture with the following composition was used: 4 vol.\% $\mathrm{H}_{2}$ and 96 vol. $\% \mathrm{O}_{2}$. The reaction medium was $100 \mathrm{~mL}$ of a $0.03 \mathrm{M} \mathrm{H}_{2} \mathrm{SO}_{4}$ methanol solution. Catalyst loading of $50 \mathrm{mg}$ was used. After the catalyst addition the suspension was stirred and then kept for $20 \mathrm{~min}$ in an ultrasonic bath. After that samples were pretreated in situ at room temperature first by $\mathrm{H}_{2}$ [30 min, $30 \mathrm{ml}$ (STP) $\mathrm{min}^{-1}$ ] and then by $\mathrm{O}_{2}\left(20 \mathrm{~min}, 30 \mathrm{scm}^{3} \mathrm{~min}^{-1}\right)$. Prior to starting the reaction, reactor was purged with $\mathrm{He}$ [50 $\mathrm{ml}$ (STP) $\min ^{-1}$ ]. During catalytic tests small aliquots of the liquid phase were sampled through a septum and used for hydrogen peroxide concentration determination.

$\mathrm{H}_{2} \mathrm{O}_{2}$ concentration was measured by iodometric titration. $\mathrm{H}_{2}$ concentrations at the inlet and the outlet of the reactor were measured by a quadrupole MS (Stanford research). The catalyst's performance was characterized in terms of the $\mathrm{H}_{2} \mathrm{O}_{2}$ concentration in methanol solutions $\left(\left[\mathrm{H}_{2} \mathrm{O}_{2}\right]\right), \mathrm{H}_{2}$ conversion $\left(\mathrm{X}_{\mathrm{H} 2}\right)$ and the selectivity toward $\mathrm{H}_{2} \mathrm{O}_{2}$ synthesis $\left(\mathrm{S}_{\mathrm{H} 2 \mathrm{O} 2}\right)$, which were calculated from the following equations:

$$
\mathrm{X}_{\mathrm{H}_{2}}=\frac{\left[\mathrm{H}_{2}\right]_{\text {inlet }}-\left[\mathrm{H}_{2}\right]_{\text {outlet }}}{\left[\mathrm{H}_{2}\right]_{\text {inlet }}} \cdot 100 \% \text {, }
$$

$$
\mathrm{S}_{\mathrm{H}_{2} \mathrm{O}_{2}}=\frac{\mathrm{n}_{\mathrm{H}_{2} \mathrm{O}_{2}}}{\Delta \mathrm{n}_{\mathrm{H}_{2}}} \cdot 100 \%
$$

where $\left[\mathrm{H}_{2}\right]_{\text {inlet }}$ and $\left[\mathrm{H}_{2}\right]_{\text {outlet }}$ are the average $\mathrm{H}_{2}$ inlet and outlet concentrations during the period between aliquots sampling; $\mathrm{n}_{\mathrm{H}_{2} \mathrm{O}_{2}}$ is the amount of $\mathrm{H}_{2} \mathrm{O}_{2}$ formed during the period between aliquots sampling; $\Delta \mathrm{n}_{\mathrm{H}_{2}}$ is the amount of $\mathrm{H}_{2}$ consumed during the period between aliquots sampling.

The catalyst loading and reaction temperature were optimized in order to make hydrogen conversion insensitive to stirring speed.

Experiments on $\mathrm{H}_{2} \mathrm{O}_{2}$ decomposition and hydrogenation were carried out at the same conditions as $\mathrm{H}_{2} \mathrm{O}_{2}$ synthesis. The initial $\mathrm{H}_{2} \mathrm{O}_{2}$ concentration was set to ca. $70 \mathrm{mM}\left(70 \cdot 10^{-3} \mathrm{~mol}\right.$ $\mathrm{L}^{-1}$ ), gas feed composition: pure $\mathrm{He}$ for $\mathrm{H}_{2} \mathrm{O}_{2}$ decomposition and 4 vol. $\% \mathrm{H}_{2}$ and 96 vol.\% $\mathrm{He}$ for $\mathrm{H}_{2} \mathrm{O}_{2}$ hydrogenation tests. The gas flow was set to $50 \mathrm{scm}^{3} \mathrm{~min}^{-1}$. $\mathrm{H}_{2} \mathrm{O}_{2}$ concentration was measured one time per hour during $5 \mathrm{~h}$.

Pure PSi support was treated by the water-acetone solution using the protocol described in section Catalyst Preparation and was tested in $\mathrm{H}_{2} \mathrm{O}_{2}$ synthesis, decomposition and hydrogenation. PSi did not show any activity in this reaction. Thus, one can conclude that PSi material is inert with regard to $\mathrm{H}_{2} \mathrm{O}_{2}$ synthesis, decomposition, and hydrogenation and could be successfully used as a catalyst support for direct synthesis of $\mathrm{H}_{2} \mathrm{O}_{2}$.

\section{Catalyst Characterization}

The as-prepared catalysts were characterized by a number of physico-chemical techniques. The chemical composition of the catalysts was determined by inductively coupled plasma atomic emission spectrometry (an Optima instrument).

The specific BET surface area $\left(\mathrm{S}_{\mathrm{BET}}\right)$ and pore volume $\left(\mathrm{V}_{\mathrm{p}}\right)$ of the catalysts were determined from the complete nitrogen adsorption isotherms at $-196^{\circ} \mathrm{C}$ (ASAP 2400 instrument).

$\mathrm{XRD}$ analysis of the as-synthesized sample powders was performed on a "DRON-SEIFERT-RM4" diffractometer $\left(\mathrm{Cu} K_{\alpha}\right.$ irradiation, graphite monochromator $d_{001}=3.345 \AA$, room temperature). The scanning range was $20^{\circ}-55^{\circ}(2 \theta)$ with a step of $0.1^{\circ}$. The experimental diffraction data were processed using the PowderCell v.2.4 (Kraus and Nolze, 2000) and WINFIT 1.2.1 (Krumm, 1996) programs, which allowed a calculation of the quantitative phase composition, the lattice parameters, and the crystallite size $\left(\mathrm{D}_{\mathrm{XRD}}\right)$. Data from the JCPDS-ICDD database (Powder Diffraction File, 2009) were used as reference. The composition of the $\mathrm{Au}_{\mathrm{x}} \mathrm{Pd}_{1-\mathrm{x}}$ alloys was determined using the experimentally measured dependence between lattice parameters of face-centered cubic cell (fcc, space group Fm-3m) in gold-palladium solid solutions and the atomic fraction of constituent elements (Shubin et al., 2012).

Transmission electron microscopy (TEM) study was performed using a JEM-2010 (lattice plane resolution $0.14 \mathrm{~nm}$ at accelerating voltage of $200 \mathrm{kV}$ ) equipped with an energydispersive X-ray (EDX) spectrometer EDAX [Si(Li) detector with $130 \mathrm{eV}$ energy resolution]. The samples for the TEM study were prepared on perforated carbon film mounted on a copper grid. 
Fourier transform infrared spectroscopy (FTIR) analysis of the catalyst samples was performed using Shimadzu IRAffinity spectrometer using $\mathrm{KBr}$ as a diluent.

X-ray photoelectron spectroscopic (XPS) analysis was performed using an ES-300 (KRATOS Analytical) photoelectron spectrometer. $\mathrm{MgK} \alpha(\mathrm{h} v=1253.6 \mathrm{eV}) \mathrm{X}$-ray source was applied for spectra registration. The spectrometer calibration was performed using bulk gold $\left(\mathrm{Au}_{4} \mathrm{f}_{7 / 2}\right)$ and copper $\left(\mathrm{Cu} 2 \mathrm{p}_{3 / 2}\right)$ photoelectron lines with binding energy (BE) values of 84.0 and $932.7 \mathrm{eV}$, respectively. The position of the $\mathrm{Si} 2 \mathrm{p}$ line for oxidized silicon with $\mathrm{BE}=103.3 \mathrm{eV}$ was used as reference for spectra calibration. Due to the overlapping of Au4d- and Pd3d- spectral regions (Smolentseva et al., 2011), the subtraction of Au4d line from Au/PSi sample was applied for all bimetallic catalysts to analyze palladium surface species precisely. The chemical composition of the surface was quantitatively determined from integral peak areas using standard atomic sensitivity factors (ASFs) (Wagner et al., 2013). Processing of the obtained data and spectral analyses were performed using homemade XPSCalc program, which has been tested on a number of systems (Svintsitskiy et al., 2013). The curve fitting procedure was performed using an approximation based on a combination of the Gaussian and Lorentzian functions with the subtraction of a Shirley-type background. Before the curve fitting, all spectra were smoothed using a Fourier filter. No considerable difference between the smoothed and experimental curves was observed (standard deviation $<1 \%$ ).

\section{RESULTS}

\section{Catalysts Characterization}

Table 1 shows actual metal loading, specific surface area and pore volume of the prepared samples. The metal loading was close to the calculated value for all the samples studied. $\mathrm{S}_{\mathrm{BET}}$ changed from $154 \mathrm{~m}^{2} \mathrm{~g}^{-1}$ for the pure PSi to $104 \mathrm{~m}^{2} \mathrm{~g}^{-1}$ for the $\mathrm{PdAu}_{2} / \mathrm{PSi}$, respectively. $\mathrm{V}_{\mathrm{p}}$ decreased synchronously with $S_{\mathrm{BET}}$ from $0.25 \mathrm{~cm}^{3} \mathrm{~g}^{-1}$ for the pure PSi to $0.17 \mathrm{~cm}^{3} \mathrm{~g}^{-1}$ for the $\mathrm{PdAu}_{2} / \mathrm{PSi}$.

PSi contains surface $\mathrm{H}$-terminal atoms, which can act as an internal surface reducing agent facilitating metal reduction. The presence of such H-terminal atoms in fresh (as received samples stored on air) non-oxidized PSi support and catalyst samples was monitored by FTIR. Figure 2 shows IR-spectra of the PSi support before catalyst preparation and of Pd/PSi, Au/PSi, Pd$\mathrm{Au} / \mathrm{PSi}$, and $\mathrm{PdAu}_{2} / \mathrm{PSi}$ catalysts. The PSi spectrum contains the stretching modes of $\mathrm{Si}-\mathrm{H}_{\mathrm{x}}$ bonds $\left(2,082,2,107\right.$, and $2,132 \mathrm{~cm}^{-1}$ for $x=1,2$, and 3, respectively) (Ogata et al., 2000; Polisski et al., 2010). The IR-spectra of the catalysts do not show stretching modes of $\mathrm{Si}-\mathrm{H}_{\mathrm{x}}$ bonds, indicating that all $\mathrm{H}$-terminal atoms were spent during catalysts preparation.

Figure 3 shows XRD patterns of the catalysts studied and of the PSi support. The silicon phase $\left(2 \Theta=47.30^{\circ}\right)$ was identified for all the samples. For the Pd/PSi and the Au/PSi catalysts, metallic $\mathrm{Pd}\left(2 \Theta=40.15^{\circ}\right.$ and $\left.46.70^{\circ}\right)$ with the crystallite size $\left(\mathrm{D}_{\mathrm{XRD}}\right)$ of $12 \mathrm{~nm}$ and $\mathrm{Au}\left(2 \Theta=38.32^{\circ}\right.$ and $44.62^{\circ}$ ) with the crystallite size of $5 \mathrm{~nm}$, respectively, were identified, see also Table 2 . The XRD pattern of Pd-Au/PSi contains not fully resolved peaks at $2 \Theta=40.08^{\circ}$ and $39.02^{\circ}$, which could be assigned to metallic $\mathrm{Pd}\left(\mathrm{D}_{\mathrm{XRD}}=6.3 \mathrm{~nm}\right)$ and solid solution $\mathrm{Pd}_{0.35} \mathrm{Au}_{0.65}\left(\mathrm{D}_{\mathrm{XRD}}=5.5 \mathrm{~nm}\right)$. Bimetallic nanoparticles are gold-enriched compared to the data on elemental composition, Table $\mathbf{1}$, due to the presence of significant amount of monometallic Pd nanoparticles. The XRD pattern of $\mathrm{PdAu}_{2} / \mathrm{PSi}$ catalyst contains broad peaks at $2 \Theta=38.79^{\circ} \mathrm{U}$ $45.01^{\circ}$, which could be assigned to the solid solution $\operatorname{Pd}_{0.25} A_{0.75}$ nanoparticles with the crystallite size of $4 \mathrm{~nm}$. The composition of $\mathrm{Pd}_{0.25} \mathrm{Au}_{0.75}$ solid solution is relatively close to the stoichiometry of DCS and data on elemental composition, Table 1. Most likely, small enrichment by gold is caused by the presence of pure Pd particles, which is confirmed by the presence of a shoulder at the position of metallic $\mathrm{Pd}$, Figure 3. The obtained data allows us to estimate that $c a .2 / 3^{\mathrm{s}}$ of $\mathrm{Pd}$ in the $\mathrm{PdAu}_{2} / \mathrm{PSi}$ catalyst is present in the form of bimetallic particles, while $1 / 3 \mathrm{rd}$ is present in the form of pure Pd. Assuming the similar particle size and taking into account the significant dilution by gold in the bimetallic particles the quantitative ratio of bimetallic to pure Pd particles in the catalyst could be estimated to be not $<8$, thus indicating that the majority of particles are bimetallic.

$\mathrm{PdAu}_{2} / \mathrm{PSi}$ and Pd-Au/PSi catalysts were studied by TEM and EDX. $\mathrm{PdAu}_{2} / \mathrm{PSi}$ contains agglomerates of bimetallic nanoparticles with the sizes in the range of $5-10 \mathrm{~nm}$, see Figures 4a,b. According to the EDX data, composition of the nanoparticles is non-uniform: some particles are enriched by $\mathrm{Pd}$. However, the average composition of agglomerates is close to $\mathrm{Pd}_{0.25} \mathrm{Au}_{0.75}$, that was also identified by the XRD. Figures $4 \mathbf{c}, \mathbf{d}$ show that $\mathrm{Pd}-\mathrm{Au} / \mathrm{PSi}$ also contains the agglomerates of bimetallic nanoparticles with the sizes in the range of $3-20 \mathrm{~nm}$. The composition of nanoparticles is non-uniform and varies from pure Pd to Au-enriched alloys. The peaks of Pd-Au alloys at XRD patterns of $\mathrm{PdAu}_{2} / \mathrm{PSi}$ and $\mathrm{Pd}-\mathrm{Au} / \mathrm{PSi}$ catalysts have a certain

TABLE 1 | Catalyst's metal loading, specific BET surface area and pore volume.

\begin{tabular}{|c|c|c|c|c|c|c|}
\hline Catalyst & Precursor & $\mathrm{S}_{\mathrm{BET}}, \mathrm{m}^{2} / \mathrm{g}$ & $v_{p}, \mathrm{~cm}^{3} / g$ & Pd, wt. \% & Au, wt. $\%$ & $\begin{array}{c}\mathrm{Pd} /(\mathrm{Pd}+\mathrm{Au}) \text { atomic } \\
\text { ratio }\end{array}$ \\
\hline PSi & - & 154 & 0.25 & 0 & 0 & - \\
\hline $\mathrm{Au} / \mathrm{PSi}$ & $\mathrm{H}\left[\mathrm{AuCl}_{4}\right]$ & 133 & 0.20 & 0 & 5 & 1 \\
\hline $\mathrm{Pd} / \mathrm{PSi}$ & {$\left[\mathrm{Pd}\left(\mathrm{NH}_{3}\right)_{4}\right]\left(\mathrm{NO}_{3}\right)_{2}$} & 141 & 0.20 & 2.1 & 0 & 0 \\
\hline Pd-Au/PSi & $\mathrm{H}_{2}\left[\mathrm{PdCl}_{4}\right]+\mathrm{H}\left[\mathrm{AuCl}_{4}\right]$ & 127 & 0.19 & 2.1 & 2 & 0.66 \\
\hline $\mathrm{PdAu}_{2} / \mathrm{PSi}$ & {$\left[\mathrm{Pd}\left(\mathrm{NH}_{3}\right)_{4}\right]\left[\mathrm{AuCl}_{4}\right]_{2}$} & 104 & 0.17 & 1.9 & 7.3 & 0.33 \\
\hline
\end{tabular}




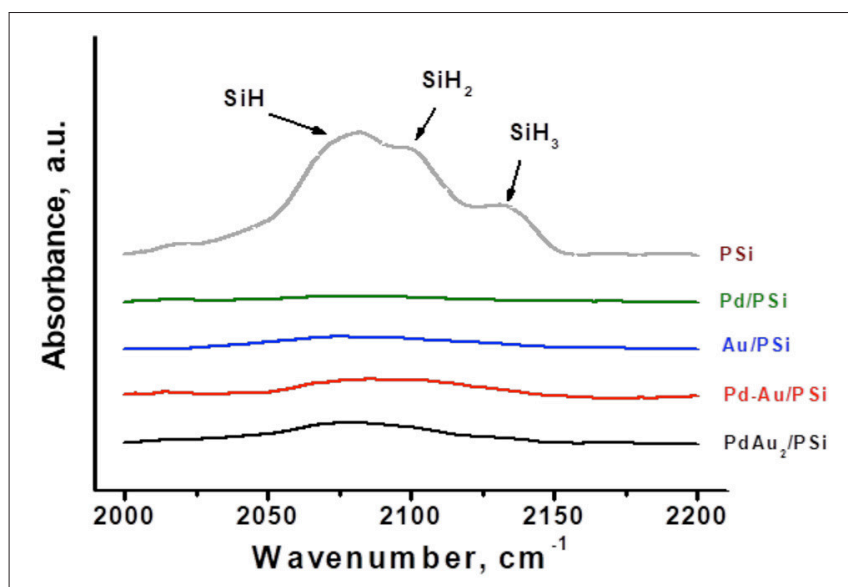

FIGURE 2 | The IR-spectra of PSi support and Pd/PSi, Au/PSi, Pd-Au/PSi, and $\mathrm{PdAu}_{2} / \mathrm{PSi}$ catalysts.

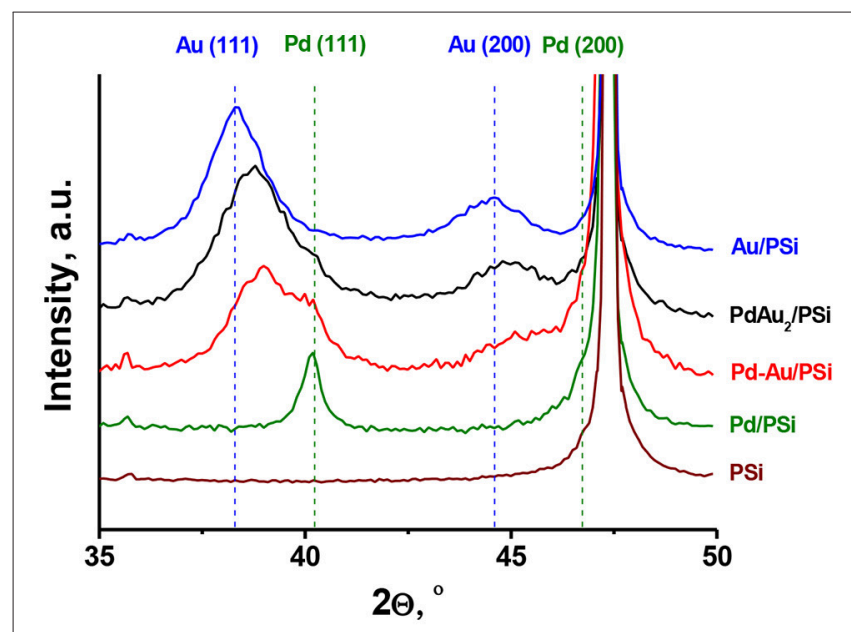

FIGURE 3 | XRD patterns of PSi support and Pd/PSi, Au/PSi, Pd-Au/PSi, and $\mathrm{PdAu}_{2} / \mathrm{PSi}$ catalysts.

TABLE 2 | Catalysts phase composition, relating to Figure $\mathbf{3}$.

\begin{tabular}{lcc}
\hline Catalyst & Phase composition & Crystallite size (D \\
\hline $\mathrm{AuRD} / \mathrm{PSi}$ & $\mathrm{Au}$ & 5 \\
$\mathrm{Pd} / \mathrm{PSi}$ & $\mathrm{Pd}$ & 12 \\
$\mathrm{Pd}-\mathrm{Au} / \mathrm{PSi}$ & $\mathrm{Pd}_{0.35} \mathrm{Au}_{0.65}$ & 5.5 \\
& $\mathrm{Pd}$ & 6.3 \\
$\mathrm{PdAu} / \mathrm{PSi}$ & $\mathrm{Pd}_{0.25} \mathrm{Au}_{0.75}$ & 4 \\
\hline
\end{tabular}

degree of asymmetry, indicating the non-uniformity of alloy nanoparticles composition, in a good agreement with EDX data. The analysis of distribution of particles composition and complex XRD fitting requires much wider array of TEM and EDX data and is out of the scope of this work. However, the majority of metallic particles in $\mathrm{Pd}-\mathrm{Au} / \mathrm{PSi}$ and practically all in $\mathrm{PdAu} / 2$ PSi catalysts are bimetallic.
Figure 5 shows the X-ray photoelectron spectra of the bimetallic Pd-Au catalysts in comparison with the monometallic $\mathrm{Pd} / \mathrm{PSi}$ and $\mathrm{Au} / \mathrm{PSi}$ samples. Spectral Si2p-regions were the same for all studied samples and consisted of three components with $\mathrm{BE}(\mathrm{Si} 2 \mathrm{p})$ of $\sim 99,101$ and $103.3 \mathrm{eV}$. According to the literature data, Si2p peaks with $\mathrm{BE} \sim 99$ and $103.3 \mathrm{eV}$ can be attributed to $\mathrm{Si}^{0}$ and oxidized $\mathrm{Si}^{4+}\left(\mathrm{SiO}_{2}\right.$-type) species, respectively (Wagner et al., 2013). The position of oxidized $\mathrm{Si}^{4+}$ peak was found to be stable during spectra registration and was chosen as a reference for spectra calibration. The Si2p peak with $\mathrm{BE} \sim 101 \mathrm{eV}$ was characterized by the lowest intensity and could be interpreted as an interface $\mathrm{SiO}_{\mathrm{x}}$ between silicon and surface oxidized $\mathrm{SiO}_{2}$ type layer. The quantitative ratio between different silicon states is given in Table 3. Therefore, surface of porous silicon used as a support material was found to be partially oxidized, which is expected for PSi materials not stored in an oxygen-free environment.

Quantitative XPS analysis has also shown that surface Pd amount was similar for bimetallic and monometallic samples ( $\mathrm{Pd} / \mathrm{Si} \sim 0.013)$, while gold amount was found to be lower for bimetallic catalyst ( $\mathrm{Au} / \mathrm{Si} \sim 0.006$ and 0.0025 ) than for $\mathrm{Au} / \mathrm{PSi}(\mathrm{Au} / \mathrm{Si} \sim 0.031)$. This indicates enrichment of the surface of the bimetallic samples by palladium. Surface palladium enrichment can be caused by interaction with oxygen followed by formation of the oxidized palladium species (Hilaire et al., 1981). As seen from Figure 5, two doublet components with $\mathrm{BE} \sim 335.2$ and $336.6 \mathrm{eV}$ identified as $\mathrm{Pd}_{3} \mathrm{~d}_{5 / 2}$ were observed in Pd3d spectra for all studied samples. The doublet with $\mathrm{BE}$ $\sim 335.2 \mathrm{eV}$ can be attributed to metallic palladium, while the second Pd3d component is caused by the presence of oxidized $\mathrm{Pd}^{2+}$ state, probably, in PdO form (Smolentseva et al., 2011). Hence, the observed segregation of palladium can be related to the process of surface oxidation. The amount of $\mathrm{Pd}^{2+}$ was similar for all the studied catalysts and equal to ca. $30 \%$, see Table 3.

Detailed XPS analysis of the Au-containing samples showed presence of two Au4f doublet components with $\mathrm{BE} \sim 83.7$ and $85.1 \mathrm{eV}\left(\mathrm{Au}_{4} \mathrm{f}_{7 / 2}\right)$. These were attributed to metallic $\mathrm{Au}^{0}$ and weakly oxidized $\mathrm{Au}^{\delta+}$ species, respectively (Ballestero et al., 2015).

Results of the analysis of the catalysts' surface composition reveal that the surface of the bimetallic Pd-Au nanoparticles is enriched by $\mathrm{Pd}$ atoms present in $\mathrm{Pd}^{0}$ and $\mathrm{Pd}^{2+}$ states. It should be noted that according to literature (Ouyang et al., 2015) the presence of both, $\mathrm{Pd}^{0}$ and $\mathrm{PdO}$, forms on the catalysts surface is required for the catalysts to be active in direct synthesis of $\mathrm{H}_{2} \mathrm{O}_{2}$.

One can conclude that the $\mathrm{Pd}-\mathrm{Au} / \mathrm{PSi}$ catalyst prepared by the conventional $\mathrm{H}_{2}\left[\mathrm{PdCl}_{4}\right]$ and $\mathrm{H}\left[\mathrm{AuCl}_{4}\right]$ precursors contains monometallic $\mathrm{Pd}$ and a wide range of different $\mathrm{Pd}-\mathrm{Au}$ solid solution nanoparticles over the oxidized PSi surface, whereas the $\mathrm{PdAu}_{2} / \mathrm{PSi}$ catalyst prepared by $\left[\mathrm{Pd}\left(\mathrm{NH}_{3}\right)_{4}\right]\left[\mathrm{AuCl}_{4}\right]_{2}$ DCS single-source precursor reduction predominantly contains bimetallic $\mathrm{Pd}-\mathrm{Au}$ solid solution nanoparticles with the composition close to $\operatorname{Pd}_{0.25} \mathrm{Au}_{0.75}$. For both catalysts surface of bimetallic nanoparticles is Pd-enriched and contains palladium in $\mathrm{Pd}^{0}$ and $\mathrm{Pd}^{2+}$ states. 

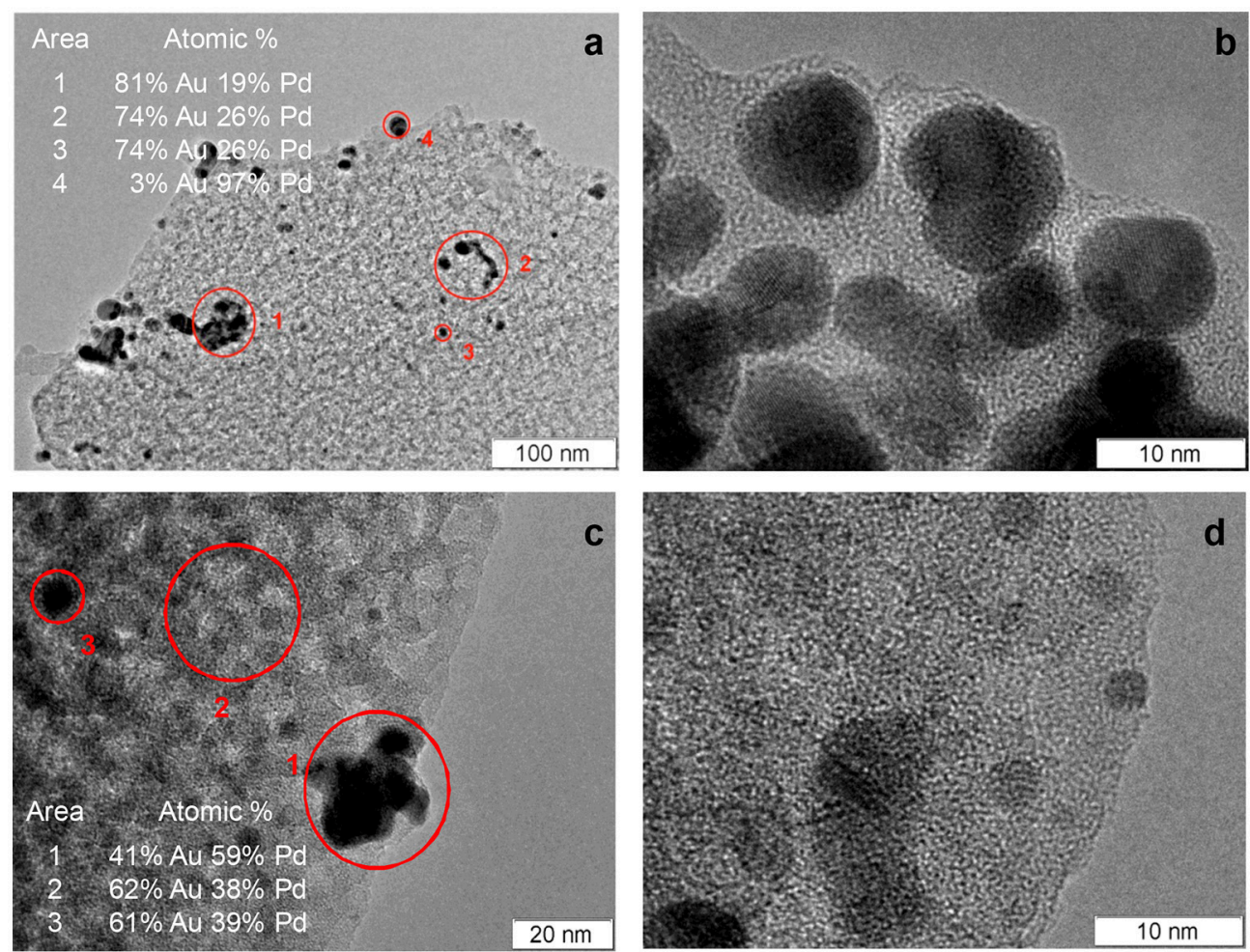

FIGURE 4 | TEM images of PdAun $/$ PSi $(\mathbf{a}, \mathbf{b})$ and Pd-Au/PSi $(\mathbf{c}, \mathbf{d})$ catalysts and EDX analysis data $\mathbf{( a , c ) .}$

\section{$\mathrm{H}_{2} \mathrm{O}_{2}$ Direct Synthesis}

The PSi supported catalysts were tested in $\mathrm{H}_{2} \mathrm{O}_{2}$ direct synthesis at $\mathrm{T}=-10^{\circ} \mathrm{C}$ and $\mathrm{P}=1$ bar in a batch reactor with bubbling $\mathrm{H}_{2}-\mathrm{O}_{2}$ gas mixture and $0.03 \mathrm{M} \mathrm{H}_{2} \mathrm{SO}_{4}$ methanol solution as a reaction media. Methanol could be suggested as one of the best solvents for this reaction due to high $\mathrm{H}_{2}$ and $\mathrm{O}_{2}$ solubilities, inability to form dangerous organic peroxides and the fact that it is a favorable solvent for many oxidation reactions involving $\mathrm{H}_{2} \mathrm{O}_{2}$ (Melada et al., 2006), such as propylene epoxidation process (Biasi et al., 2013).

After each catalytic test the catalyst powder was filtered and the residual reaction media was tested in the reaction conditions for $1 \mathrm{~h}$ in order to check metal leaching from the catalysts. None of the filtrates showed any activity in $\mathrm{H}_{2} \mathrm{O}_{2}$ synthesis or decomposition, indicating that PSi-supported metallic nanoparticles were stable under the reaction conditions tested, or leached metals were inactive in any relevant catalytic reactions. Filtered catalyst powders were recycled to the 2nd $3 \mathrm{~h}$ long catalytic run and properties of all catalysts were fully reproduced with respect to amount of catalyst recycled.

Figure 6 shows the time course of $\mathrm{H}_{2} \mathrm{O}_{2}$ concentration (Figure 6A), $\mathrm{H}_{2}$ conversion (Figure 6B) and selectivity (Figure 6C) for the direct $\mathrm{H}_{2} \mathrm{O}_{2}$ synthesis over $\mathrm{Pd} / \mathrm{PSi}$, $\mathrm{Au} / \mathrm{PSi}, \mathrm{Pd}-\mathrm{Au} / \mathrm{PSi}$, and $\mathrm{PdAu}_{2} / \mathrm{PSi}$ catalysts. It is seen that the $\mathrm{Au} / \mathrm{PSi}$ catalyst was inactive in the direct $\mathrm{H}_{2} \mathrm{O}_{2}$ synthesis as well as in complete $\mathrm{H}_{2}$ oxidation: $\mathrm{H}_{2}$ conversion was $<4 \%$. The Pd-containing catalysts were active in the direct $\mathrm{H}_{2} \mathrm{O}_{2}$ synthesis. For all the Pd-based catalysts $\mathrm{H}_{2} \mathrm{O}_{2}$ concentration grows nearly linearly with time, $\mathrm{H}_{2}$ conversion is constant, while selectivity slowly decreases. The $\mathrm{H}_{2} \mathrm{O}_{2}$ concentration of ca. $6 \mathrm{mM}$ was reached over $\mathrm{Pd} / \mathrm{PSi}$ after $5 \mathrm{~h}$ on stream at $\mathrm{X}_{\mathrm{H} 2}$ of $10 \%$ and $\mathrm{S}_{\mathrm{H} 2 \mathrm{O} 2}$ decrease from 25 to $20 \%$. The Pd-Au/PSi catalyst was more active: $\left[\mathrm{H}_{2} \mathrm{O}_{2}\right]$ of $c a .9 \mathrm{mM}$ was reached after $5 \mathrm{~h}$ on stream at $\mathrm{X}_{\mathrm{H} 2}$ of $15 \%$ and $\mathrm{S}_{\mathrm{H} 2 \mathrm{O} 2}$ decrease from 25 to $20 \%$. The $\mathrm{Pd} / \mathrm{PSi}$ and Pd-Au/PSi catalysts exhibited similar selectivity vs. time dependencies. This could be associated with the presence of monometallic Pd nanoparticles in both catalysts. Higher activity of Pd-Au/PSi could be associated with higher metal dispersion.

The $\mathrm{PdAu}_{2} / \mathrm{PSi}$ catalyst exhibited the best performance in the direct $\mathrm{H}_{2} \mathrm{O}_{2}$ synthesis. $\mathrm{H}_{2} \mathrm{O}_{2}$ concentration of $c a .23 \mathrm{mM}$ was reached after $5 \mathrm{~h}$ on stream at $\mathrm{X}_{\mathrm{H} 2}$ of $23 \%$ and $\mathrm{S}_{\mathrm{H} 2 \mathrm{O} 2}$ decreases from ca. 50 to $c a$. $45 \%$. High activity of $\mathrm{PdAu}_{2} / \mathrm{PSi}$ in $\mathrm{H}_{2}$ oxidation could be associated with high metal dispersion $\left(4 \mathrm{~nm}\right.$ for $\mathrm{PdAu}_{2} / \mathrm{PSi}$ vs. $5-6 \mathrm{~nm}$ for Pd-Au/PSi vs. $12 \mathrm{~nm}$ for $\mathrm{Pd} / \mathrm{PSi}$ ), while high selectivity toward $\mathrm{H}_{2} \mathrm{O}_{2}$ synthesis could be associated with the major part of $\mathrm{Pd}$ in the catalyst being in the form of bimetallic Pd-Au nanoparticles, since monometallic $\mathrm{Pd}$ nanoparticles are known to be active in the undesirable $\mathrm{H}_{2} \mathrm{O}_{2}$ hydrogenation reaction. The obtained data on $\mathrm{H}_{2} \mathrm{O}_{2}$ direct synthesis shows that bimetallic PSi-supported catalysts are more active and selective (in the case of $\mathrm{PdAu}_{2} / \mathrm{PSi}$ ), compared with the monometallic $\mathrm{Pd} / \mathrm{PSi}$, which is not surprising (Edwards et al., 2015; Li and Yoshizawa, 2015). 

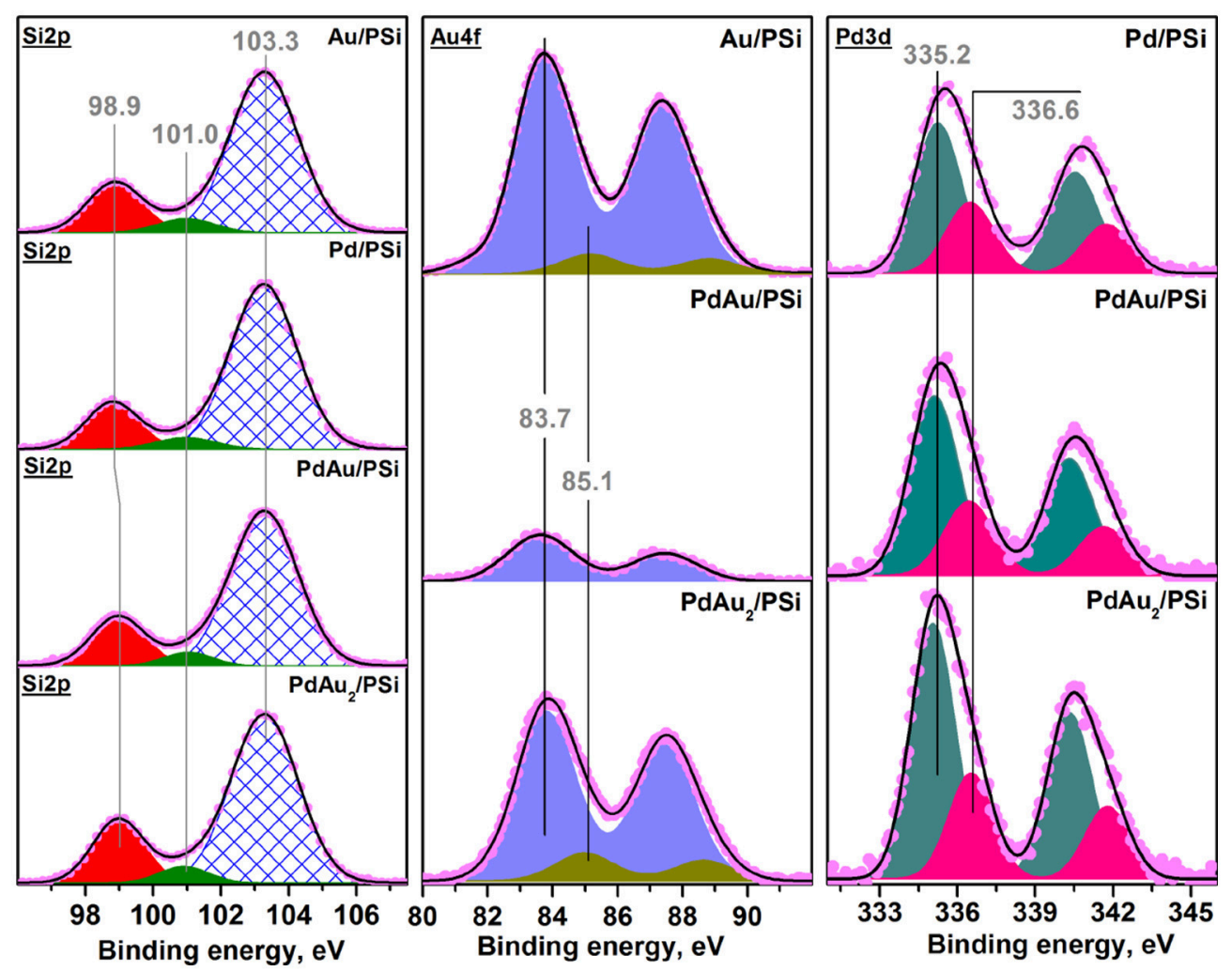

FIGURE 5 | Photoelectron Si2p-, Au4f-, and Pd3d- XP spectra of Pd/PSi, Au/PSi, Pd-Au/PSi, and PdAun/PSi catalysts.

TABLE 3 | XPS data on the surface composition of the catalysts.

\begin{tabular}{lcccc}
\hline Catalyst & Pd/PSi & Au/PSi & Pd-Au/PSi & PdAu $/$ PSi \\
\hline$(\mathrm{Pd} / \mathrm{Si}) \cdot 10^{2}$ & 1.3 & - & 1.1 & 1.4 \\
$(\mathrm{Au} / \mathrm{Si}) \cdot 10^{2}$ & - & 3.1 & 0.6 & 2.5 \\
$\mathrm{Pd} / \mathrm{Au}$ & - & - & 1.8 & 0.6 \\
$\mathrm{Pd}^{2+}, \%$ & 31 & - & 27 & 29 \\
$\mathrm{Au}^{\delta+}, \%$ & - & 8 & - & 13 \\
$\mathrm{Si}^{0}, \%$ & 18 & 60 & 19 & 22 \\
$\mathrm{SiO}_{\mathbf{x}}, \%$ & 5 & 75 & 6 & 5 \\
$\mathrm{Si}^{4+}, \%$ & 77 & & 75 & 73 \\
\hline
\end{tabular}

It was shown, that for $\mathrm{Pd} / \mathrm{PSi}, \mathrm{Pd}-\mathrm{Au} / \mathrm{PSi}$, and $\mathrm{PdAu}_{2} / \mathrm{PSi}$ catalysts selectivity of $\mathrm{H}_{2} \mathrm{O}_{2}$ synthesis slowly decreased with time, while $\mathrm{H}_{2}$ conversion remained constant (Figures 6B,C). It could be caused by the occurrence of the undesirable $\mathrm{H}_{2} \mathrm{O}_{2}$ decomposition and hydrogenation reactions. In order to elucidate the influence of these reactions the $\mathrm{H}_{2} \mathrm{O}_{2}$ decomposition and hydrogenation reactions were studied over PSi-supported catalysts.

\section{$\mathrm{H}_{2} \mathrm{O}_{2}$ Decomposition and Hydrogenation}

In order to study stability of the synthesized $\mathrm{H}_{2} \mathrm{O}_{2}$ at the reaction conditions a number of experiments on $\mathrm{H}_{2} \mathrm{O}_{2}$ decomposition and hydrogenation were carried out. Experimental conditions were close to that for $\mathrm{H}_{2} \mathrm{O}_{2}$ synthesis in this work. As initial reaction media $0.07 \mathrm{M} \mathrm{H}_{2} \mathrm{O}_{2} / 0.03 \mathrm{M} \mathrm{H}_{2} \mathrm{SO}_{4}$ methanol solution was chosen. The reactions were carried out at $-10^{\circ} \mathrm{C}$.

At first, the reaction of $\mathrm{H}_{2} \mathrm{O}_{2}$ decomposition was studied. Figure 7A shows the time course of $\mathrm{H}_{2} \mathrm{O}_{2}$ concentration for $\mathrm{H}_{2} \mathrm{O}_{2}$ decomposition over $\mathrm{Pd} / \mathrm{PSi}, \mathrm{Au} / \mathrm{PSi}, \mathrm{Pd}-\mathrm{Au} / \mathrm{PSi}$, and $\mathrm{PdAu}_{2} / \mathrm{PSi}$ catalysts. It is seen, that $\mathrm{H}_{2} \mathrm{O}_{2}$ concentration was constant for the $\mathrm{Pd} / \mathrm{PSi}, \mathrm{Au} / \mathrm{PSi}$, and $\mathrm{PdAu}_{2} / \mathrm{PSi}$ catalysts and negligibly decreased in the case of $\mathrm{Pd}-\mathrm{Au} / \mathrm{PSi}$. This indicates that all studied catalysts were generally inactive in $\mathrm{H}_{2} \mathrm{O}_{2}$ decomposition.

Figure 7B shows the results on $\mathrm{H}_{2} \mathrm{O}_{2}$ hydrogenation over the $\mathrm{Pd} / \mathrm{PSi}, \mathrm{Au} / \mathrm{PSi}, \mathrm{Pd}-\mathrm{Au} / \mathrm{PSi}$, and $\mathrm{PdAu}_{2} / \mathrm{PSi}$ catalysts. It is seen, that $\mathrm{H}_{2} \mathrm{O}_{2}$ concentration was practically constant during $5 \mathrm{~h}$ over $\mathrm{Au} / \mathrm{PSi}$, indicating that $\mathrm{Au} / \mathrm{PSi}$ was practically inactive in $\mathrm{H}_{2} \mathrm{O}_{2}$ hydrogenation. Over $\mathrm{Pd} / \mathrm{PSi}$ and $\mathrm{PdAu}_{2} / \mathrm{PSi}$ catalysts $\mathrm{H}_{2} \mathrm{O}_{2}$ concentration slowly decreased from $70 \mathrm{mM}$ to $c a .55 \mathrm{mM}$ after $5 \mathrm{~h}$ on stream. Pd-Au/PSi was the most active one in $\mathrm{H}_{2} \mathrm{O}_{2}$ hydrogenation: $\mathrm{H}_{2} \mathrm{O}_{2}$ concentration decreased from 70 to $36 \mathrm{mM}$ after $5 \mathrm{~h}$ on stream. The differences in behavior of the Pd-based catalysts are caused by the different phase compositions and dispersions of the active component. The $\mathrm{PdAu}_{2} / \mathrm{PSi}$ catalyst was less active in $\mathrm{H}_{2} \mathrm{O}_{2}$ hydrogenation than $\mathrm{Pd}-\mathrm{Au} / \mathrm{PSi}$ and $\mathrm{Pd} / \mathrm{PSi}$ despite the higher metal dispersion due to the presence of the major part of $\mathrm{Pd}$ in the catalyst in the form of bimetallic $\mathrm{Pd}-\mathrm{Au}$ nanoparticles. 

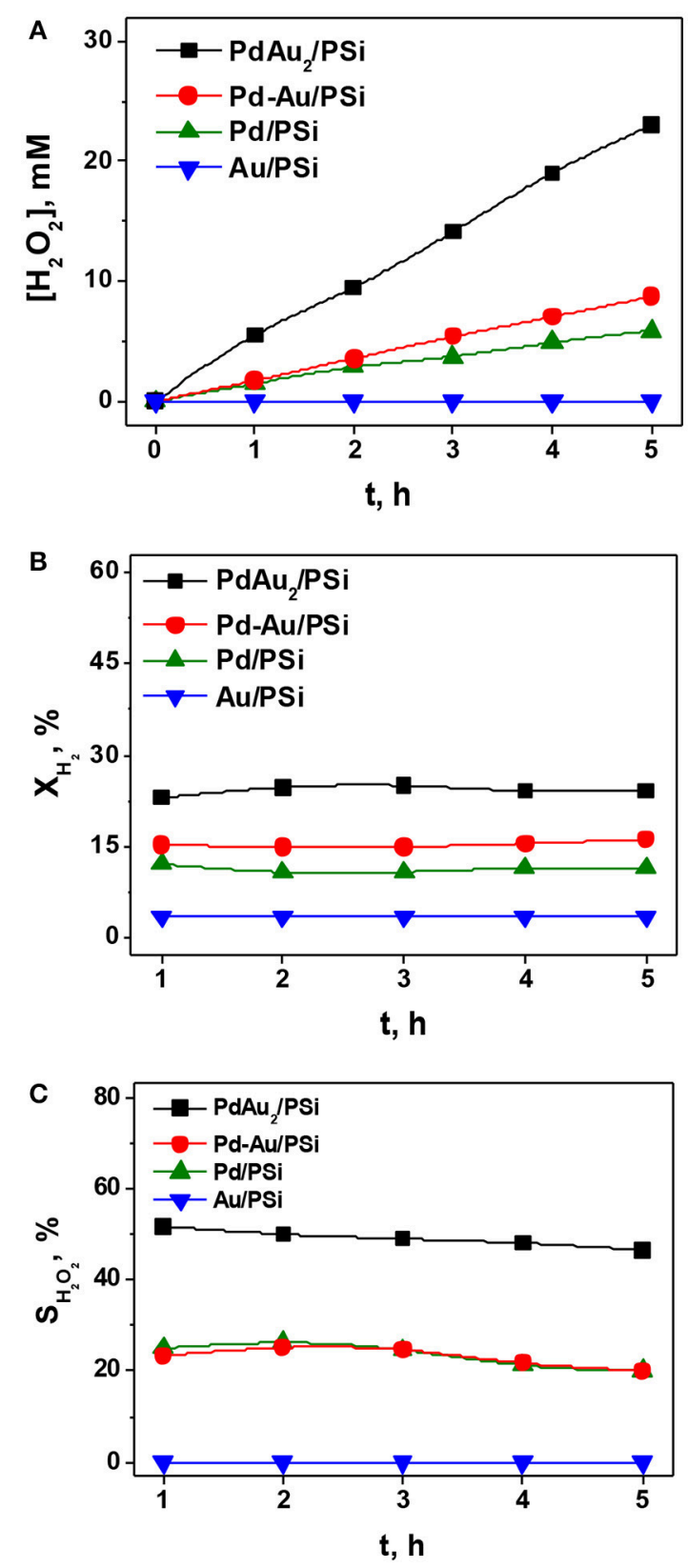

FIGURE 6 | The time course of the $\mathrm{H}_{2} \mathrm{O}_{2}$ concentration (A), $\mathrm{H}_{2}$ conversion (B), and $\mathrm{H}_{2} \mathrm{O}_{2}$ selectivity (C) for the direct $\mathrm{H}_{2} \mathrm{O}_{2}$ synthesis over the $\mathrm{Pd} / \mathrm{PSi}$, $\mathrm{Au} / \mathrm{PSi}, \mathrm{Pd}-\mathrm{Au} / \mathrm{PSi}$, and $\mathrm{PdAu} / 2 / \mathrm{PSi}$ catalysts. $\mathrm{P}=1$ bar. $\mathrm{T}=-10^{\circ} \mathrm{C}$. Reaction media: $100 \mathrm{~mL}$ of a $0.03 \mathrm{M} \mathrm{H}_{2} \mathrm{SO}_{4}$ methanol solution. Gas flow rate: $2 \mathrm{ml}$ (STP) $\mathrm{min}^{-1} \mathrm{H}_{2}$ and $48 \mathrm{ml}(\mathrm{STP}) \mathrm{min}^{-1} \mathrm{O}_{2}$. Catalyst loading: $50 \mathrm{mg}$.

Thus, one can conclude that, unlike $\mathrm{H}_{2} \mathrm{O}_{2}$ decomposition, $\mathrm{H}_{2} \mathrm{O}_{2}$ hydrogenation significantly influences direct $\mathrm{H}_{2} \mathrm{O}_{2}$ synthesis over the $\mathrm{Pd} / \mathrm{PSi}, \mathrm{Pd}-\mathrm{Au} / \mathrm{PSi}$ and $\mathrm{PdAu}_{2} / \mathrm{PSi}$ catalysts, decreasing reaction selectivity and limiting the maximum reachable $\mathrm{H}_{2} \mathrm{O}_{2}$ concentration. Among the catalysts studied the $\mathrm{PdAu}_{2} / \mathrm{PSi}$ is the least active in $\mathrm{H}_{2} \mathrm{O}_{2}$ hydrogenation.
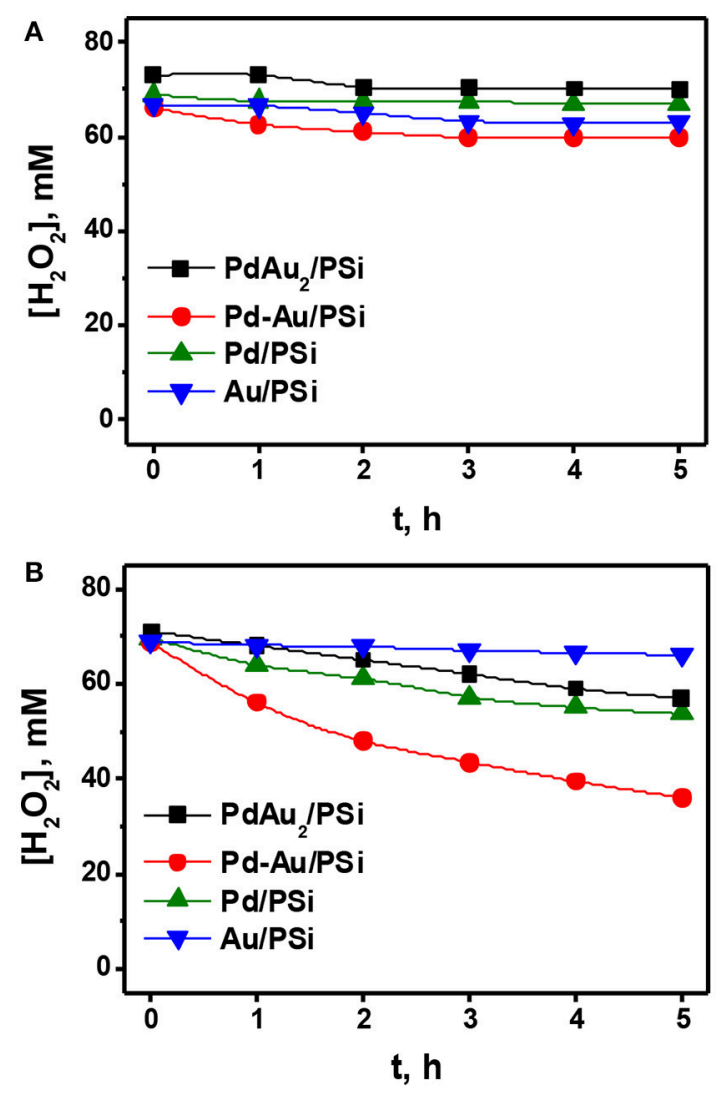

FIGURE 7 | The time course of the $\mathrm{H}_{2} \mathrm{O}_{2}$ concentration for the $\mathrm{H}_{2} \mathrm{O}_{2}$ decomposition (A) and reduction (B) over the Pd/PSi, Au/PSi, Pd-Au/PSi and $\mathrm{PdAu}_{2} / \mathrm{PSi}$ catalysts. $\mathrm{P}=1$ bar. $\mathrm{T}=-10^{\circ} \mathrm{C}$. Reaction media: $100 \mathrm{~mL}$ of a ca. $70 \mathrm{mM} / 0.03 \mathrm{M} \mathrm{H}_{2} \mathrm{SO}_{4}$ methanol solution. Gas flow rate: (A) $50 \mathrm{ml}$ (STP) $\mathrm{min}^{-1} \mathrm{He}$; (B) $2 \mathrm{ml}$ (STP) $\mathrm{min}^{-1} \mathrm{H}_{2}$; and $48 \mathrm{ml}$ (STP) $\mathrm{min}^{-1} \mathrm{He}$. Catalyst loading: $50 \mathrm{mg}$.

\section{DISCUSSION}

Among the catalysts studied in the present work the $\mathrm{PdAu}_{2} / \mathrm{PSi}$ one showed the highest activity and selectivity in the direct synthesis of $\mathrm{H}_{2} \mathrm{O}_{2}$. This is due to its high activity in $\mathrm{H}_{2} \mathrm{O}_{2}$ synthesis reaction as well as low activity in the undesirable $\mathrm{H}_{2} \mathrm{O}_{2}$ decomposition and hydrogenation side reactions. We assign excellent performance of the $\mathrm{PdAu}_{2} / \mathrm{PSi}$ catalyst to the fact that most of $\mathrm{Pd}$ in the catalyst is in the form of bimetallic Pd-Au nanoparticles. The preferred method of synthesis of supported bimetallic Pd-Au nanoparticles was found to be based on DCS $\left[\mathrm{Pd}\left(\mathrm{NH}_{3}\right)_{4}\right]\left[\mathrm{AuCl}_{4}\right]_{2}$ reduction inside the PSi's pore space by the surface H-terminal atoms. The alloy nanoparticles are the primary product of DCS reduction. Prevention of intermediate formation of monometallic Pd and $\mathrm{Au}$ grains allows one to obtain bimetallic nanoparticles under very mild conditions. The composition of the formed $\mathrm{Au}_{0.75} \mathrm{Pd}_{0.25}$ nanoparticles is relatively close to the DCS stoichiometry. Thus, it could be concluded, that the presence of specific chemical interaction between the $\mathrm{Pd}$ and Au precursors 
promotes formation of supported bimetallic nanoparticles and, therefore, active and selective catalyst, while the application of conventionally used joint water solutions of $\mathrm{Pd}$ and $\mathrm{Au}$ chlorides leads to the formation of a wide range of different $\mathrm{Pd}-\mathrm{Au}$ bimetallic nanoparticles as well as pure $\mathrm{Pd}$ and $\mathrm{Au}$ ones (e.g., the case of Pd-Au/PSi) (Edwards et al., 2009).

Despite the fact that surface of as received PSi was $\mathrm{H}$ terminated, the surface of as-prepared catalysts was mostly covered by a $\mathrm{SiO}_{2}$ layer. From one side it presents the possibility for strong metal-support interaction (SMSI) in the $\mathrm{Pd}_{\mathrm{x}} \mathrm{Au}_{1-\mathrm{x}}$-PSi system, which is generally favorable for $\mathrm{H}_{2} \mathrm{O}_{2}$ direct synthesis catalysts due to electron transfer from $\mathrm{Pd}$ (Yi et al., 2016). However, the SMSI effect in the Si-based systems is typically observed after high temperature reduction and is associated with silicide phases or layers formation (Ueckert et al., 1997). This is not the case here. From the other side $\mathrm{SiO}_{2}$ is an acidic support with low value of surface isoelectric point of about 2, which is desirable for stabilization of the formed $\mathrm{H}_{2} \mathrm{O}_{2}$. Also, the $\mathrm{SiO}_{2}$ layer encapsulates the possible undesirable contaminations and provides the material inertness with respect to $\mathrm{H}_{2} \mathrm{O}_{2}$ decomposition and hydrogenation reactions.

Gemo et al. (2015) and Ouyang et al. (2015) highlighted the key role of $\mathrm{Pd}^{2+} / \mathrm{Pd}^{0}$ surface ratio on the $\mathrm{Pd}$ catalysts performance in the direct synthesis of $\mathrm{H}_{2} \mathrm{O}_{2}$. Simultaneous presence of $\mathrm{Pd}^{0}$ and $\mathrm{Pd}^{2+}$ sites at the surface is required to provide dissociative $\mathrm{H}_{2}$ adsorption and non-dissociative $\mathrm{O}_{2}$ adsorption. The single-metal Pd catalysts tend to oxidation under reaction conditions that is undesirable (Gemo et al., 2015). High values of $\mathrm{H}_{2}^{\mathrm{L}} / \mathrm{Pd}$ ratio $\left(\mathrm{H}_{2}^{\mathrm{L}}\right.$-the concentration of hydrogen dissolved in liquid media) and Pd particle size increase lead to the stabilization of $\mathrm{Pd}^{0}$ surface sites. We believe that $\mathrm{Au}$ addition to $\mathrm{Pd}$ together with selective formation of $\mathrm{Pd}-\mathrm{Au}$ bimetallic particles increases its resistance toward oxidation as $\mathrm{Au}$ is a "very noble" metal. The $\mathrm{Pd}-\mathrm{Au}$ particle size in the $\mathrm{PdAu}_{2} / \mathrm{PSi}$ catalyst is not very small. All these factors protect Pd surface from deep oxidation under reaction conditions and help to provide the acceptable $\mathrm{Pd}^{2+} / \mathrm{Pd}^{0}$ surface ratio and reach higher $\mathrm{H}_{2} \mathrm{O}_{2}$ selectivity.

The properties of $\mathrm{PdAu}_{2} / \mathrm{PSi}$ in direct $\mathrm{H}_{2} \mathrm{O}_{2}$ synthesis were compared with other Pd-based catalytic systems. Table 4 summarizes the literature data on catalytic performance and reaction conditions. $\mathrm{PdAu}_{2} / \mathrm{PSi}$ catalyst studied in the present work showed the $\mathrm{H}_{2} \mathrm{O}_{2}$ productivity of $0.5 \mathrm{~mol} \mathrm{~g}_{\mathrm{Pd}}^{-1} \mathrm{~h}^{-1}$ or $12.3 \mathrm{~mol} \mathrm{~kg}_{\text {cat }}^{-1} \mathrm{~h}^{-1}$ at selectivity of $50 \%$, that is lower than the productivity of the best-known catalysts. The lower $\mathrm{H}_{2} \mathrm{O}_{2}$ production rate could be associated with low reaction temperature of $-10^{\circ} \mathrm{C}$. The highest values of productivity were obtained for $\mathrm{Pd}_{0.1} \mathrm{Au}_{0.0333} \mathrm{Cs}_{2.5} \mathrm{H}_{0.2} \mathrm{PW}_{12} \mathrm{O}_{40}\left(29.4 \mathrm{~mol} \mathrm{~g}_{\mathrm{Pd}}^{-1} \mathrm{~h}^{-1}\right)$ (Ntainjua et al., 2012) and $\mathrm{Pd}-\mathrm{Au} / \mathrm{C}\left(6.4 \mathrm{~mol} \mathrm{~g}_{\mathrm{Pd}}^{-1} \mathrm{~h}^{-1}\right)$ (Edwards et al., 2009) catalysts. However, these studies utilized elevated pressures of 40 and 37 atm, respectively. In the works Bernardotto et al. (2009) and Ouyang et al. (2015), the experiments were carried at atmospheric pressure and the productivity values of $3.0 \mathrm{~mol} \mathrm{~g}_{\mathrm{Pd}}^{-1} \mathrm{~h}^{-1}$ for $\mathrm{Pd} / \mathrm{TiO}_{2}$

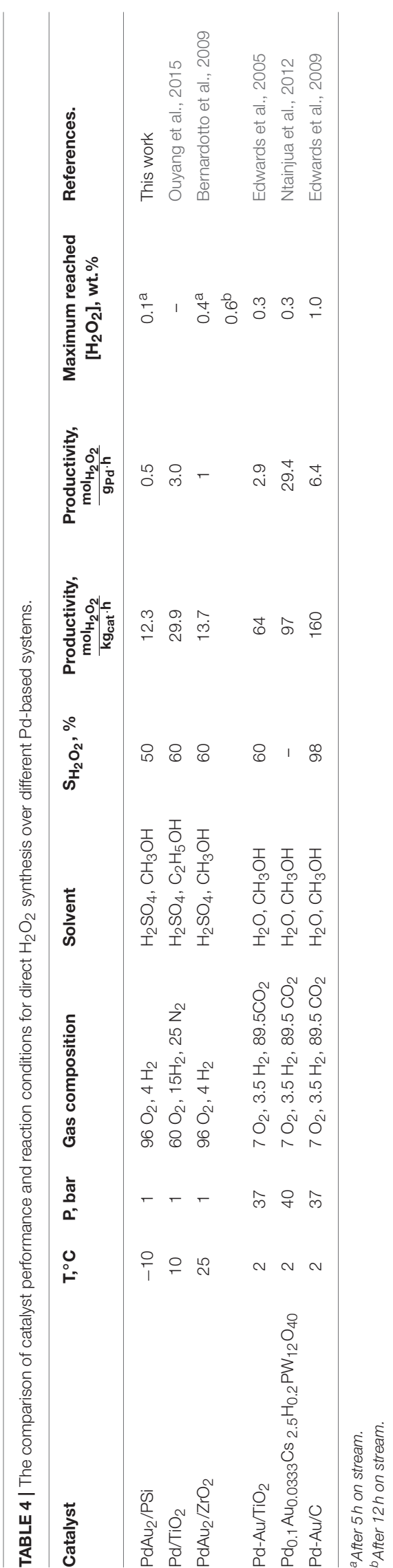

Frontiers in Chemistry | www.frontiersin.org 
(Svintsitskiy et al., 2013) and $1.0 \mathrm{~mol} \mathrm{~g}_{\mathrm{Pd}}^{-1} \mathrm{~h}^{-1}$ for $\mathrm{PdAu} / \mathrm{ZrO}_{2}$ (Bernardotto et al., 2009) were obtained. These are closer to the results obtained for the $\mathrm{PdAu}_{2} / \mathrm{PSi}$ catalyst, taking into account the higher reaction temperatures: $10^{\circ} \mathrm{C}$ for $\mathrm{Pd} / \mathrm{TiO}_{2}$ and $25^{\circ} \mathrm{C}$ for $\mathrm{PdAu}_{2} / \mathrm{ZrO}_{2}$. Also, similar selectivities were obtained: $60 \%$ for $\mathrm{Pd} / \mathrm{TiO}_{2}$ and $\mathrm{PdAu}_{2} / \mathrm{ZrO}_{2}$ vs. $50 \%$ for $\mathrm{PdAu}_{2} / \mathrm{PSi}$.

As indicated above, the minimal required $\mathrm{H}_{2} \mathrm{O}_{2}$ concentration produced by direct synthesis for practical applications is estimated to be $1 \mathrm{wt}$.\% or $0.23 \mathrm{M}$ in a methanol solution (GarciaSerna et al., 2014). In Edwards et al. (2005) and Ntainjua et al. (2012) the maximum reached $\mathrm{H}_{2} \mathrm{O}_{2}$ concentration was $c a .0 .3$ wt.\% and was limited by the reaction of $\mathrm{H}_{2} \mathrm{O}_{2}$ hydrogenation. The perfectly selective $\mathrm{Pd}-\mathrm{Au} / \mathrm{C}$ catalyst allowed to reach $\mathrm{H}_{2} \mathrm{O}_{2}$ concentration of more than 1.0 wt.\% by several gas topups in a closed batch system at 37 bar pressure and $2^{\circ} \mathrm{C}$ (Edwards et al., 2009). The closer conditions of atmospheric pressure and flowing gas feed were utilized in Bernardotto et al. (2009) and $\mathrm{H}_{2} \mathrm{O}_{2}$ concentrations of 0.4 and 0.6 wt.\% were reached after 5 and $12 \mathrm{~h}$ on stream, respectively. Thus, the target of 1.0 wt.\% was likely achievable. In the present work the maximum $\mathrm{H}_{2} \mathrm{O}_{2}$ concentration reached is 0.1 wt.\% after $5 \mathrm{~h}$ on stream, which is less than that of the best catalysts. The estimation of $\mathrm{H}_{2} \mathrm{O}_{2}$ synthesis and hydrogenation rates for $\mathrm{PdAu}_{2} / \mathrm{PSi}$ catalyst gives the maximum achievable $\mathrm{H}_{2} \mathrm{O}_{2}$ concentration at the level of $c a .0 .8$ wt.\%, which could be reached by increasing reaction time and/or catalyst loading.

Thus, it is clear, that further catalyst improvement is required. However, even at this point of development it is clear, that PSi supported bimetallic Pd-Au system is a promising system to be used in the continuous flow systems for direct $\mathrm{H}_{2} \mathrm{O}_{2}$ synthesis. Applying the electrochemical etching technique, a layer of porous silicon could be fabricated directly on the silicon microchannel's surface and used as a support (Drott et al., 1997) for Pd$\mathrm{Au}$ catalyst, avoiding the need of laborious catalyst deposition procedure. If so, silicon microreactors with a porous silicon layer onto the channel walls with deposited $\mathrm{Pd}-\mathrm{Au}$ nanoparticles is a very intriguing option for performing $\mathrm{H}_{2} \mathrm{O}_{2}$ direct synthesis due to enhanced control abilities (Srinivas et al., 2004; Huang et al., 2014), possibility of safe operation at high temperatures and pressures (Divins et al., 2011) and wide range of reactor geometries available.

\section{CONCLUSIONS}

In conclusion, we would like to point out key features of DCS application as a precursor and porous silicon as a support for direct $\mathrm{H}_{2} \mathrm{O}_{2}$ synthesis catalysts:

\section{REFERENCES}

Ballestero, D., Juan, R., Ibarra, A., Gómez-Giménez, C., Ruiz, C., Rubio, B., et al. (2015). Effect of thermal treatments on the morphology, chemical state and lattice structure of gold nanoparticles deposited onto carbon structured monoliths. Colloids Surf. A 468, 140-150. doi: 10.1016/j.colsurfa.2014.12.017
- The DCS $\left[\mathrm{Pd}\left(\mathrm{NH}_{3}\right)_{4}\right]\left[\mathrm{AuCl}_{4}\right]_{2}$ reduction inside the pore space of the support promotes the selective formation of Pd-Au alloy nanoparticles under very mild conditions.

- The composition of formed supported bimetallic Pd-Au nanoparticles is close to the stoichiometry of DCS.

- The Pd-Au catalysts prepared by DCS $\left[\mathrm{Pd}\left(\mathrm{NH}_{3}\right)_{4}\right]\left[\mathrm{AuCl}_{4}\right]_{2}$ reduction is active in direct $\mathrm{H}_{2} \mathrm{O}_{2}$ synthesis.

- PSi is porous material that could effectively enhance dispersion of supported metal nanoparticles.

- PSi with partially oxidized surface is an inert material with respect to undesirable $\mathrm{H}_{2} \mathrm{O}_{2}$ decomposition and hydrogenation reactions and thus could be used as a catalysts support for direct $\mathrm{H}_{2} \mathrm{O}_{2}$ synthesis reaction.

- The surface of PSi-supported catalysts is coated by $\mathrm{Si}^{0}$ and $\mathrm{SiO}_{2}$ sites and thus PSi could be easily wetted by different solvents, such as water, methanol, ethanol, and others.

- PSi supported Pd-Au catalysts are quite active and selective in direct $\mathrm{H}_{2} \mathrm{O}_{2}$ synthesis.

- PSi's surface H-terminal atoms could effectively reduce different $\mathrm{Pd}$ and $\mathrm{Au}$ precursors with the formation of bimetallic Pd-Au alloy nanoparticles. Thus bimetallic Pd$\mathrm{Au}$ nanoparticles could be easily deposited onto already established PSi layer.

- PSi is a promising support for direct hydrogen peroxide synthesis from engineering point of view due to its high thermal stability and conductivity, possibility of safe operation at high temperatures and pressures, and well-established silicon processing techniques, providing the possibility to design reactors of complex internal geometry with surface porous silicon layers.

\section{AUTHOR CONTRIBUTIONS}

DP: catalytic experiments, overall results analysis; DM: catalytic experiments; KL: FTIR experiments; PS: catalyst preparation, BET analysis; YS: XRD analysis; PP: precursors preparation, ICP AES analysis; DS: XPS analysis; VS: results analysis; AL: concept of PSi-supported catalysts, supervision of catalyst testing, and manuscript preparation and editing.

\section{ACKNOWLEDGMENTS}

The authors are grateful to Dr. V. I. Zaikowskii for assistance in HRTEM analysis. The work was supported by RFBR Grant 16-33-60106_mol_a_dk. This research was, in part, supported by the National Research Foundation, Prime Minister's Office, Singapore, under its CREATE program. We gratefully acknowledge inspiration to work with porous silicon from our former colleague, late Professor DK. 
of $\mathrm{H} 2 \mathrm{O} 2$ from $\mathrm{H} 2$ and $\mathrm{O} 2$ under very mild conditions. Appl. Catal. A 358, 129-135. doi: 10.1016/j.apcata.2009.02.010

Biasi, P., Garcia-Serna, J., Bittante, A., and Salmi, T. (2013). Direct synthesis of hydrogen peroxide in water in a continuous trickle bed reactor optimized to maximize productivity. Green Chem. 15, 2502-2513. doi: 10.1039/c3gc40811f

Bulushev, D. A., Beloshapkin, S., Plyusnin, P. E., Shubin, Y. V., Bukhtiyarov, V. I., Korenev, S. V., et al. (2013). Vapour phase formic acid decomposition over $\mathrm{PdAu} / \gamma$-Al2O3 catalysts: effect of composition of metallic particles. J. Catal. 299, 171-180. doi: 10.1016/j.jcat.2012.12.009

Climent, M. J., Corma, A., Iborra, S., and Sabater, M. J. (2014). Heterogeneous catalysis for tandem reactions ACS Catal. 4, 870-891. doi: 10.1021/cs401052k

Coulthard, I., and Sham, T. K. (1998). Novel preparation of noble metal nanostructures utilising porous silicon. Solid State Commun. 105, 751-754. doi: 10.1016/S0038-1098(97)10229-0

Coulthard, I., de Jiang, T., Lorimer, J. W., Sham, T. K., and Feng, X. H. (1993). Reductive deposition of $\mathrm{Pd}$ on porous silicon from aqueous solutions of PdCl2: an X-ray absorption fine structure study. Langmuir 9, 3441-3445. doi: $10.1021 / \mathrm{la} 00036 \mathrm{a} 018$

Coulthard, I., Sammynaiken, R., Naftel, S. J., Zhang, P., and Sham, T. K. (2000). Porous silicon: a template for the preparation of nanophase metals and bimetallic aggregates. Phys. Stat. Sol. A 182, 157-162. doi: 10.1002/1521-396X(200011)182:1<157::AID-PSSA157>3.0.CO;2-O

Dasog, M., Kraus, S., Sinelnikov, R., Veinot, G. C., and Rieger, B. (2017). CO2 to methanol conversion using hydride terminated porous silicon nanoparticles. Chem. Commun. 53, 3114-3117. doi: 10.1039/C7CC00125H

Dhakshinamoorthy, A., Opanasenko, M., Cejka, J., and Garcia, H. (2013). Metal organic frameworks as heterogeneous catalysts for the production of fine chemicals. Catal. Sci. Technol. 3, 2509-2540. doi: 10.1039/c3cy00350g

Dittmeyer, R., Grunwaldt, J. D., and Pashkova, A. (2015). A review of catalyst performance and novel reaction engineering concepts in direct synthesis of hydrogen peroxide. Catal. Today 248, 149-159. doi: 10.1016/j.cattod.2014.03.055

Divins, N. J., López, E., Roig, M., Trifonov, T., Rodríguez, A., de Rivera, F. G., et al. (2011). A million-channel CO-PrOx microreactor on a fingertip for fuel cell application. Chem. Eng. J. 167, 597-602. doi: 10.1016/j.cej.2010.07.072

Drott, J., Lindström, K., Rosengren, L., and Laurell, T. (1997). Porous silicon as the carrier matrix in microstructured enzyme reactors yielding high enzyme activities. J. Micromech. Microeng. 7, 14-23. doi: 10.1088/0960-1317/7/ $1 / 004$

Edwards, J. K., Freakley, S. J., Lewis, R. J., Pritchard, J. C., and Hutchings, G. J. (2015). Advances in the direct synthesis of hydrogen peroxide from hydrogen and oxygen. Catal. Today 248, 3-9. doi: 10.1016/j.cattod.2014.03.011

Edwards, J. K., Pritchard, J., Piccinini, M., Shaw, G., He, Q., Carley, A. F., et al. (2012). The effect of heat treatment on the performance and structure of carbon-supported $\mathrm{Au}-\mathrm{Pd}$ catalysts for the direct synthesis of hydrogen peroxide. J. Catal. 292, 227-238. doi: 10.1016/j.jcat.2012.05.018

Edwards, J. K., Solsona, B. E., Landon, P., Carley, A. F., Herzing, A., Kiely, C. J., et al. (2005). Direct synthesis of hydrogen peroxide from $\mathrm{H} 2$ and $\mathrm{O} 2$ using TiO2-supported Au-Pd catalysts. J. Catal. 236, 69-79. doi: 10.1016/j.jcat.2005.09.015

Edwards, J. K., Solsona, B., Ntainjua, E., Carley, A. F., Herzing, A. A., Kiely, C. J., et al. (2009). Switching off hydrogen peroxide hydrogenation in the direct synthesis process. Science 323, 1037-1041. doi: 10.1126/science.1168980

Ensafi, A. A., Jafari-Asl, M., Rezaei, B., Abarghoui, M. M., and Farrokhpour, H. (2015). Facile synthesis of Pt-Pd@Silicon nanostructure as an advanced electrocatalyst for direct methanol fuel cells. J. Power Sources 282, 452-461. doi: 10.1016/j.jpowsour.2015.02.065

Fan, X., Zhang, G., and Zhang, F. (2015). Multiple roles of graphene in heterogeneous catalysis. Chem. Soc. Rev. 44, 3023-3035. doi: $10.1039 /$ C5CS00094G

Flytzani-Stephanopoulos, and Gates, B. C. (2012). Atomically dispersed supported metal catalysts. Annu. Rev. Chem. Biomol. Eng. 3, 545-574. doi: 10.1146/annurev-chembioeng-062011-080939

Freakley, S. J., He, Q., Harrhy, J. H., Lu, L., Crole, D. A., Morgan, D. J., et al. (2016). Palladium-tin catalysts for the direct synthesis of $\mathrm{H}_{2} \mathrm{O}_{2}$ with high selectivity. Science 351, 965-968. doi: 10.1126/science.aad5705

Freakley, S. J., Piccinini, M., Edwards, J. K., Ntainjua, E. N., Moulijn, J. A., and Hutchings, G. J. (2013). Effect of reaction conditions on the direct synthesis of hydrogen peroxide with a $\mathrm{AuPd} / \mathrm{TiO} 2$ catalyst in a flow reactor. ACS Catal. 3 , 487-501. doi: 10.1021/cs400004y

Garcia-Serna, J., Moreno, T., Biasi, P., Cocero, M. J., Mikkola, J.-P., and Salmi, T. O. (2014). Engineering in direct synthesis of hydrogen peroxide: targets, reactors and guidelines for operational conditions. Green Chem. 16, 2320-2343. doi: $10.1039 / \mathrm{c} 3 \mathrm{gc} 41600 \mathrm{c}$

Gemo, N., Sterchele, S., Biasi, P., Centomo, P., Canu, P., Zecca, M., et al. (2015). The influence of catalyst amount and Pd loading on the $\mathrm{H}_{2} \mathrm{O}_{2}$ synthesis from hydrogen and oxygen. Catal. Sci. Technol. 5, 3545-3555. doi: 10.1039/C5CY00493D

Gu, J., Wang, S., He, Z., Han, Y., and Zhang, J. (2016). Direct synthesis of hydrogen peroxide from hydrogen and oxygen over activated-carbon-supported Pd-Ag alloy catalysts. Catal. Sci. Technol. 6, 809-817. doi: 10.1039/C5CY00813A

Hilaire, L., Légaré, P., Holl, Y., and Maire, G. (1981). Interaction of oxygen and hydrogen with Pd-Au alloys: an AES and XPS study. Surf. Sci. 103, 125-140. doi: 10.1016/0039-6028(81)90103-5

Huang, C. C., Huang, Y. J., Wang, H. S., Tseng, F. G., and Su, Y. C. (2014). A well-dispersed catalyst on porous silicon micro-reformer for enhancing adhesion in the catalyst-coating process. Int. J. Hydrogen Ener. 39, 7753-7764. doi: 10.1016/j.ijhydene.2014.03.029

Hulkoti, N. I., and Taranath, T. C. (2014). Biosynthesis of nanoparticles using microbes - a review. Colloids Surf. B Biointerfaces 121, 474-483. doi: 10.1016/j.colsurfb.2014.05.027

Julkapli, N. M., and Bagheri, S. (2015). Graphene supported heterogeneous catalysts: an overview. Int. J. Hydrogen Energy 40, 948-979. doi: $10.1016 /$ j.ijhydene.2014.10.129

Kraus, W., and Nolze, G. (2000). POWDERCELL 2.4, Program for the Representation and Manipulation of Crystal Structures and Calculation of the Resulting X-ray Powder Patterns. Berlin: Federal Institute for Materials Research and Testing.

Krumm, S. (1996). An interactive windows program for profile fitting and size/strain analysis. Mater. Sci. Forum 228-231, 183-190. doi: 10.4028/www.scientific.net/MSF.228-231.183

Künzner, N., Gross, E., Diener, J., Kovalev, D., Timoshenko, V. Y., and Wallacher, D. (2003). Capillary condensation monitored in birefringent porous silicon layers. J. Appl. Phys. 94, 4913-4917. doi: 10.1063/1.1609643

Lehmann, V., Stengl, R., and Luigart, A. (2000). On the morphology and the electrochemical formation mechanism of mesoporous silicon. Mater. Sci. Eng. B 69-70, 11-22. doi: 10.1016/S0921-5107(99)00286-X

Li, J., and Yoshizawa, K. (2015). Mechanistic aspects in the direct synthesis of hydrogen peroxide on PdAu catalyst from first principles. Catal. Today 248, 142-148. doi: 10.1016/j.cattod.2014.04.009

Litovchenko, V. G., Gorbanyuk, T. I., and Solntsev, V. S. (2017). Mechanism of adsorption-catalytic activity at the nanostructured surface of silicon doped with clusters of transition metals and their oxides. Ukr. J. Phys. 62, 605-614. doi: 10.15407/ujpe62.07.0605

Maity, S., and Eswaramoorthy, M. (2016). Ni-Pd bimetallic catalysts for the direct synthesis of $\mathrm{H}_{2} \mathrm{O}_{2}$ - unusual enhancement of Pd activity in the presence of Ni. J. Mater. Chem. A 4, 3233-3237. doi: 10.1039/C6TA00486E

Melada, S., Rioda, R., Menegazzo, F., Pinna, F., and Strukul, G. (2006). Direct synthesis of hydrogen peroxide on zirconia-supported catalysts under mild conditions. J. Catal. 239, 422-430. doi: 10.1016/j.jcat.2006.02.014

Menegazzo, F., Manzoli, M., Signoretto, M., Pinna, F., and Strukul, G. (2015). $\mathrm{H} 2 \mathrm{O} 2$ direct synthesis under mild conditions on Pd-Au samples: effect of the morphology and of the composition of the metallic phase. Catal. Today 248, 18-27. doi: 10.1016/j.cattod.2014.01.015

Munnik, P., de Jongh, P. E., and de Jong, K. P. (2015). Recent developments in the synthesis of supported catalysts. Chem. Rev. 115, 6687-6718. doi: $10.1021 /$ cr500486u

Ntainjua, E. N., Piccinini, M., Freakley, S. J., Pritchard, J. C., Edwards, J. K., Carley, A. F., et al. (2012). Direct synthesis of hydrogen peroxide using AuPd-exchanged and supported heteropolyacid catalysts at ambient temperature using water as solvent. Green Chem. 14, 170-181. doi: 10.1039/C1GC15863E

Ogata, Y. H., Tsuboi, T., Sakka, T., and Naito, S. (2000). Oxidation of porous silicon in dry and wet environments under mild temperature conditions. J. Porous Mater. 7, 63-66. doi: 10.1023/A:1009694608199

Ouyang, L., Tian, P.-F., Da, G.-J., Xu, X.-C., Ao, C., Chen, T.-Y., et al. (2015). The origin of active sites for direct synthesis of $\mathrm{H} 2 \mathrm{O} 2$ on 
Pd/TiO2 catalysts: interfaces of Pd and PdO domains. J. Catal. 321, 70-80. doi: $10.1016 /$ j.jcat.2014.10.003

Plyusnin, P. E., Baidina, I. A., Shubin, Y. V., and Korenev, S. V. (2007). Synthesis, crystal structure, and thermal properties of [ $\mathrm{Pd}(\mathrm{NH} 3) 4][\mathrm{AuCl} 4] 2$. Russ. J. Inorg. Chem. 52, 371-377. doi: 10.1134/S0036023607030138

Polisski, S., Goller, B., Lapkin, A., Fairclough, S., and Kovalev, D. (2008). Synthesis and catalytic activity of hybrid metal/silicon nanocomposites. Phys. Stat. Sol. 2, 132-134. doi: 10.1002/pssr.200802076

Polisski, S., Goller, B., Wilson, K., Kovalev, D., Zaikovskii, V., and Lapkin, A. (2010). In situ synthesis and catalytic activity in CO oxidation of metal nanoparticles supported on porous nanocrystalline silicon. J. Catal. 271, 59-66. doi: 10.1016/j.jcat.2010.02.002

Potemkin, D. I., Filatov, E. Y., Zadesenets, A. V., and Sobyanin, V. A. (2017). CO preferential oxidation on Pt0.5Co0.5 and Pt-CoOx model catalysts: catalytic performance and operando XRD studies. Catal. Commun. 100, 232-236. doi: 10.1016/j.catcom.2017.07.008

Potemkin, D. I., Filatov, E. Y., Zadesenets, A. V., Snytnikov, P. V., Shubin, Y. V., and Sobyanin, V. A. (2012). Preferential CO oxidation over bimetallic PtCo catalysts prepared via double complex salt decomposition. Chem. Eng. J. 207-208, 683-689. doi: 10.1016/j.cej.2012.07.037

Potemkin, D. I., Semitut, E. Y., Shubin, Y. V., Plyusnin, P. E., Snytnikov, P. V., Makotchenko, E. V., et al. (2014). Silica, alumina and ceria supported $\mathrm{Au}-\mathrm{Cu}$ nanoparticles prepared via the decomposition of $[\mathrm{Au}(\mathrm{en}) 2] 2[\mathrm{Cu}(\mathrm{C} 2 \mathrm{O} 4) 2] 3 \bullet 8 \mathrm{H} 2 \mathrm{O}$ single-source precursor: synthesis, characterization and catalytic performance in CO PROX. Catal. Today 235, 103-111. doi: 10.1016/j.cattod.2014.04.026

Powder Diffraction File (2009). PDF-2/Release 2009. International Centre for Diffraction Data.

Samanta, C. (2008). Direct synthesis of hydrogen peroxide from hydrogen and oxygen: an overview of recent developments in the process. Appl. Catal. A 350, 133-149. doi: 10.1016/j.apcata.2008.07.043

Seo, M.-G., Kim, H. J., Han, S. S., and Lee, K.-Y. (2017). Direct synthesis of hydrogen peroxide from hydrogen and oxygen using tailored $\mathrm{Pd}$ nanocatalysts: a review of recent findings. Catal. Surv. Asia 21, 1-12. doi: 10.1007/s10563-016-9221-y

Serp, P., and Castillejos, E. (2010). Catalysis in carbon nanotubes ChemCatChem 2, 41-47. doi: 10.1002/cctc.200900283

Shubin, Y., Plyusnin, P., and Sharafutdinov, M. (2012). In situ synchrotron study of $\mathrm{Au}-\mathrm{Pd}$ nanoporous alloy formation by single-source precursor thermolysis. Nanotechnology 23:405302. doi: 10.1088/0957-4484/23/40/405302

Simonov, A. N., Plyusnin, P. E., Shubin, Y. V., Kvon, R. I., Korenev, S. V., and Parmon, V. N. (2012). Hydrogen electrooxidation over palladium-gold alloy: effect of pretreatment in ethylene on catalytic activity and CO tolerance. Electrochim. Acta 76, 344-353. doi: 10.1016/j.electacta.2012.05.043

Smolentseva, E., Kusema, B. T., Beloshapkin, S., Estrada, M., Vargas, E., Murzin, D. Y., et al. (2011). Selective oxidation of arabinose to arabinonic acid over Pd-Au catalysts supported on alumina and ceria. Appl. Catal. A 392, 69-79. doi: 10.1016/j.apcata.2010.10.021

Srinivas, S., Dhingra, A., Im, H., and Gulari, E. (2004). A scalable silicon microreactor for preferential CO oxidation: performance comparison with a tubular packed-bed microreactor. Appl. Catal. A Gen. 274, 285-293. doi: 10.1016/j.apcata.2004.07.012

Svintsitskiy, D. A., Chupakhin, A. P., Slavinskaya, E. M., Stonkus, O. A., Stadnichenko, A. I., Koscheev, S. V., et al. (2013). Study of cupric oxide nanopowders as efficient catalysts for low-temperature CO oxidation. J. Mol. Catal. A 368-369, 95-106. doi: 10.1016/j.molcata.2012.11.015
Tian, P., Xu, X., Ao, C., Ding, D., Li, W., Si, R., et al. (2017). Direct and selective synthesis of hydrogen peroxide over palladium-tellurium catalysts at ambient pressure. ChemSusChem 10, 3342-3346. doi: 10.1002/cssc.201 701238

Ueckert, T., Lamber, R., Jaeger, N. I., and Schubert, U. (1997). Strong metal support interactions in a $\mathrm{Ni} / \mathrm{SiO} 2$ catalyst prepared via sol-gel synthesis. Appl. Catal. A 155, 75-85. doi: 10.1016/S0926-860X(96)00384-5

Vedyagin, A. A., Gavrilov, M. S., Volodin, A. M., Stoyanovskii, V. O., Slavinskaya, E. M., Mishakov, I. V., et al. (2013). Catalytic purification of exhaust gases over Pd-Rh alloy catalysts. Top. Catal. 56, 1008-1014. doi: 10.1007/s11244-013-0064-8

Vedyagin, A. A., Volodin, A. M., Stoyanovskii, V. O., Kenzhin, R. M., Slavinskaya, E. M., Mishakov, I. V., et al. (2014). Stabilization of active sites in alloyed Pd-Rh catalysts on $\gamma$-Al2O3 support. Catal. Today 238, 80-86. doi: 10.1016/j.cattod.2014.02.056

Wagner, C. D., Riggs, W. M., Davis, L. E., Moulder, J. F., and Muilenberg, G. E. (2013). Handbook of X-Ray Photoelectron Spectroscopy. Eden Prairie, MN: Perkin-Elmer.

Yan, Y., Miao, J., Yang, Z., Xiao, F., Yang, H., Liu, B., et al. (2015). Carbon nanotube catalysts: recent advances in synthesis, characterization and applications. Chem. Soc. Rev. 44, 3295-3346. doi: 10.1039/C4CS00492B

Yashtulov, N. A., and Flid, V. R. (2013). Regularities of formic acid oxidation in the presence of porous silicon nanocomposites with palladium. Russ. Chem. Bull. 62, 1332-1337. doi: 10.1007/s11172-013-0188-9

Yashtulov, N. A., Gavrin, S. S., Bondarenko, V. P., Kholostov, K. I., Revina, A. A., and Flid, V. R. (2011). Formation of nanocomposite platinum catalysts on porous silicon. Russ. Chem. Bull. 60:434. doi: 10.1007/s11172-0110068-0

Yashtulov, N. A., Zenchenko, V. O., Kuleshov, N. V., and Flid, V. R. (2016). Synthesis and catalytic activity of platinum/porous silicon nanocomposites. Russ. Chem. Bull. 65, 2369-2374. doi: 10.1007/s11172-016-1591-9

Yi, Y., Wang, L., Li, G., and Guo, H. (2016). A review on research progress in the direct synthesis of hydrogen peroxide from hydrogen and oxygen: noble-metal catalytic method, fuel-cell method and plasma method. Catal. Sci. Technol. 6, 1593-1610. doi: 10.1039/C5CY01567G

Zhai, W., Ai, Q., Chen, L. N., Wei, S. Y., Li, D. P., Zhang, L., et al. (2017). Walnut-inspired microsized porous silicon/graphene core-shell composites for high-performance lithium-ion battery anodes. Nano Res. 10, 4274-4283. doi: 10.1007/s12274-017-1584-5

Zhao, M., Yuan, K., Wang, Y., Li, G., Guo, J., Gu, L., et al. (2016). Metal-organic frameworks as selectivity regulators for hydrogenation reactions. Nature 539, 76-80. doi: 10.1038/nature19763

Conflict of Interest Statement: The authors declare that the research was conducted in the absence of any commercial or financial relationships that could be construed as a potential conflict of interest.

The reviewer, YZ, and handling Editor declared their shared affiliation.

Copyright (c) 2018 Potemkin, Maslov, Loponov, Snytnikov, Shubin, Plyusnin, Svintsitskiy, Sobyanin and Lapkin. This is an open-access article distributed under the terms of the Creative Commons Attribution License (CC BY). The use, distribution or reproduction in other forums is permitted, provided the original author(s) and the copyright owner are credited and that the original publication in this journal is cited, in accordance with accepted academic practice. No use, distribution or reproduction is permitted which does not comply with these terms. 